\title{
Estrogen Receptor Alpha Prevents Bladder Cancer Development via INPP4B inhibited Akt Pathway in vitro and in vivo
}

\author{
Iawen $\mathrm{Hsu}^{1 *}$, Chiuan-Ren $\mathrm{Yeh}^{1 *}$, Spencer Slavin ${ }^{1}$, Hiroshi Miyamoto², George \\ J. Netto ${ }^{2}$, Yu-Chieh Tsai ${ }^{1}$, Mesut Muyan ${ }^{3}$, Xue-Ru Wu ${ }^{4}$, Edward M. Messing ${ }^{1}$, \\ Elizabeth A. Guancial ${ }^{5}$, Shuyuan Yeh $^{1}$ \\ 1 Departments of Urology and Pathology, University of Rochester Medical Center, Rochester, NY 14642. \\ 2 Departments of Pathology, Urology, and Oncology, The Johns Hopkins Hospital, Baltimore, MD 21231. \\ ${ }^{3}$ Department of Biochemistry \& Biophysics, University of Rochester Medical Center, Rochester, NY 14642. \\ ${ }^{4}$ Department of Urology, New York University, School of Medicine, NY 10016. \\ ${ }^{5}$ Departments of Hematology and Oncology, University of Rochester Medical Center, Rochester, NY 14642. \\ * Contributed equally \\ Correspondence to:
}

Dr. Shuyuan Yeh, e-mail: shuyuan_yeh@urmc.rochester.edu

Received: September 17, $2013 \quad$ Accepted: July 07, 2014

Published: August 13, 2014

Abbreviations: ERa, estrogen receptor alpha; ERaKO, ERa knockout mice; BCa, bladder cancer; BBN, N-butyl-N-(4-hydroxybutyl) nitrosamine; IHC, immunohistochemistry; INPP4B, Inositol polyphosphate-4-phosphatase type II; MTT, 3-(4,5-Dimethylthiazol-2-yl)2,5-Diphenyltetrazolium Bromide; MCA, 3-methylcholanthrene; WT, wild type.

\section{ABSTRACT}

Clinical reports show males have a higher bladder cancer (BCa) incidence than females. The sexual difference of $\mathrm{BCa}$ occurrence suggests that estrogen and its receptors may affect BCa development. Estrogen receptor alpha (ERa) is the classic receptor to convey estrogen signaling, however, the function of ERa in $\mathrm{BCa}$ development remains largely unknown. To understand the in vivo role of ERa in BCa development, we generated total and urothelial specific ERa knockout mice (ERaKO) and used the pre-carcinogen BBN to induce BCa. Earlier reports showed that ERa promotes breast and ovarian cancers in females. Surprisingly and of clinical importance, our results showed that ERa inhibits BCa development and loss of the ERa gene results in an earlier onset and higher incidence of $\mathrm{BBN}$-induced in vivo mouse BCa. Supportively, carcinogen induced malignant transformation ability was reduced in ERa expressing urothelial cells as compared to ERa negative cells. Mechanism studies suggest that ERa could control the expression of INPP4B to reduce AKT activity and consequently reduce BCa cell growth. In addition, IHC staining of clinical sample analyses show that INPP4B expression, in correlation with reduced ERa, is significantly reduced in human BCa specimens. Together, this is the first report using the in vivo cre-loxP gene knockout mouse model to characterize ERa roles in BCa development. Our studies provide multiple in vitro cell studies and in vivo animal model data as well as human BCa tissue analyses to prove ERa plays a protective role in BCa initiation and growth at least partly via modulating the INPP4B/Akt pathway.

\section{INTRODUCTION}

Urothelial carcinoma of the bladder is the fourth most common cancer in men and eleventh most common cancer in women in the United States [1]. It has been reported that $\mathrm{BCa}$ has the highest lifetime treatment cost per patient among all types of solid cancers [2], and most therapies for $\mathrm{BCa}$ patients will eventually fail. Thus, it is critical to understand the underlying mechanisms and find an approach to manage $\mathrm{BCa}$ development. Aging, environmental chemical exposure, and infectious parasites were found to be associated with higher $\mathrm{BCa}$ risks. Clinically, $\mathrm{BCa}$ incidence for males to females is 3.5 to 1 [3], suggesting sex hormone signals may play a role in the occurrence of $\mathrm{BCa}$. Supportively, evidence suggests androgens/androgen receptor (AR) promote $\mathrm{BCa}$ 
development [4]. However, it remains unclear whether estrogen and estrogen receptors (ERs) play roles in the BCa occurrence.

There are two major types of estrogen receptors, $\mathrm{ER} \alpha$ and $\mathrm{ER} \beta$, mediating estrogen effects in various tissues [5-9]. In addition, it has been known that estrogen and anti-estrogens will both activate a membrane protein, GPR30 [10, 11]. The roles of each ER in BCa development are understudied areas. In this report, we focused on investigating $\mathrm{ER} \alpha$ roles in $\mathrm{BCa}$ development. $\mathrm{ER} \alpha$ is a well-known transcriptional factor and belongs to the nuclear receptor superfamily. $17 \beta$-estradiol (E2), the natural ligand of $\mathrm{ER} \alpha$, can bind to and regulate $\mathrm{ER} \alpha$ downstream gene expression. Multiple mechanisms have been proposed by which $\mathrm{ER} \alpha$ can activate downstream gene expressions to exert its function [9]. In addition, growth factor signaling pathways such as EGF [12] or IGF-2 [13], can activate ER $\alpha$ in the absence of E2 in vascular or cancer cells.

The different levels of ER $\alpha$ expression in normal bladder tissues compared to BCa tissues have not been consistently reported [14-16]. However, the more recent study conducted by two independent medical institutes with $188 \mathrm{BCa}$ and 141 normal bladder tissues showed that loss of $\mathrm{ER} \alpha$ was commonly found in primary $\mathrm{BCa}$ tissues, and loss of ER $\alpha$ was strongly associated with higher grade and invasive tumors [14]. The difference between earlier reports [15-16] and the recent one [14] could possibly be attributed to improvements of antibody specificity and the methods and time periods of clinical specimen fixation $[17,18]$. To date, there has been no study carefully evaluating ER $\alpha$ mRNA levels in a large number of clinical samples of BCa vs. noncancerous specimens. With the above argument of IHC staining results [14-16], it is important to further validate the mRNA of ER $\alpha$ in clinical BCa specimens. In the present study, we analyzed 3 independent datasets to show reduced ER $\alpha$ mRNA in BCa compared to adjacent normal bladder tissues.

Currently, there have been reports of several mouse BCa models. These models include Uroplakin II promoter driven SV40 expression (UPII-SV40), N-butyl-N(4-hydroxybutyl) nitrosamine (BBN)-induced, UPIIHa-ras, etc [4, 19, 20]. Among these models, the pre-carcinogen $\mathrm{BBN}$ has been used extensively to induce $\mathrm{BCa}$ in mouse as reported in numerous publications [4, $21,22]$. BBN-induced BCa showed sexual dimorphism with males having a higher cancer incidence rate [4]. In addition, morphological characteristics of mouse BBN induced $\mathrm{BCa}$ are similar to those in humans $[23,24]$. Thus, the $\mathrm{BBN}$-induced mouse $\mathrm{BCa}$ model is widely applied as the best model to mimic human $\mathrm{BCa}$ development and was used for the present study.

Two types of categorized genes, proto-oncogenes and tumor-suppressor genes, play key roles in cancer induction. In bladder tumors, the proto-oncogene C-Met was positively associated with histologic grade, stage classification, and tumor size [25]. Pim-1, a proto-oncogene and serine/threonine-protein kinase, was expressed more in tumors than normal urothelial compartments and was higher in invasive BCa tissues [26]. Inositol polyphosphate-4-phosphatase, type II (INPP4B), a tumor suppressor, has a reduced expression in prostate and breast cancers compared to normal tissues [27, 28], yet its roles in $\mathrm{BCa}$ remain unclear. To understand $\mathrm{ER} \alpha-$ mediated inhibition role in $\mathrm{BCa}$, we screened a group of proto-oncogenes and tumor-suppressor genes, and found INPP4B was predominantly and specifically induced by ER $\alpha$. Recently, INPP4B was shown to inhibit AKT phosphorylation by hydrolyzing phosphatidylinositol $(3,4)$-bisphosphate (PtdIns(3,4)P2) [29, 30]. Other than mechanistic studies, we have investigated and found that INPP4B expression, in correlation with reduced ER $\alpha$, is reduced in human and mouse $\mathrm{BCa}$ tissues.

Together, we have utilized multiple in vitro and in vivo strategies to demonstrate $\mathrm{ER} \alpha$ plays a protective role in $\mathrm{BCa}$ development and to investigate the functional mechanisms of $\mathrm{ER} \alpha$ in $\mathrm{BCa}$.

\section{RESULTS}

\section{Reduced ER $\alpha$ mRNA in bladder cancers}

The roles of $\mathrm{ER} \alpha$ in $\mathrm{BCa}$ development are understudied. Currently, there are no available data concerning $\mathrm{ER} \alpha \mathrm{mRNA}$ level differences between normal and $\mathrm{BCa}$ tissue, and IHC staining results of ER $\alpha$ protein expression could be compromised by the antibody specificity, or the method and time of tissue fixation $[17,18]$. Also, different from the IHC results that $\mathrm{ER} \alpha$ protein is reduced in $\mathrm{BCa}$ [14], an earlier report of analyses of a small number of clinical specimen (10 cases) showed that ER $\alpha$ mRNA increases in $\mathrm{BCa}$ [16]. Thus, it was important to examine the ER $\alpha$ mRNA levels to compare with IHC results in larger numbers of clinical specimens. We analyzed mRNA expression results between normal and $\mathrm{BCa}$ tissues from the databases found in Oncomine (http://www.oncomine .org). In 3 separate microarray cohorts of bladder tissues (Study I: 48 normal tissues and 109 BCa tissues, Study II: 14 normal tissues and 46 BCa tissues, Study III: 68 normal tissues and $188 \mathrm{BCa}$ tissues) [31-33], there were significantly lower mRNA expressions of ER $\alpha$ in tumors as compared with normal bladder tissues (Fig. 1). In conclusion, our report is the first comprehensive analysis of databases from 3 independent resources for ER $\alpha$ mRNA levels, and the analyzed data show that ER $\alpha$ mRNA is reduced in $\mathrm{BCa}$. Together, Fig. $1 \mathrm{mRNA}$ data and the reported IHC results [14] show $\mathrm{ER} \alpha \mathrm{mRNA}$ and protein decrease in $\mathrm{BCa}$ and $\mathrm{ER} \alpha$ may play protective roles in $\mathrm{BCa}$ development. 

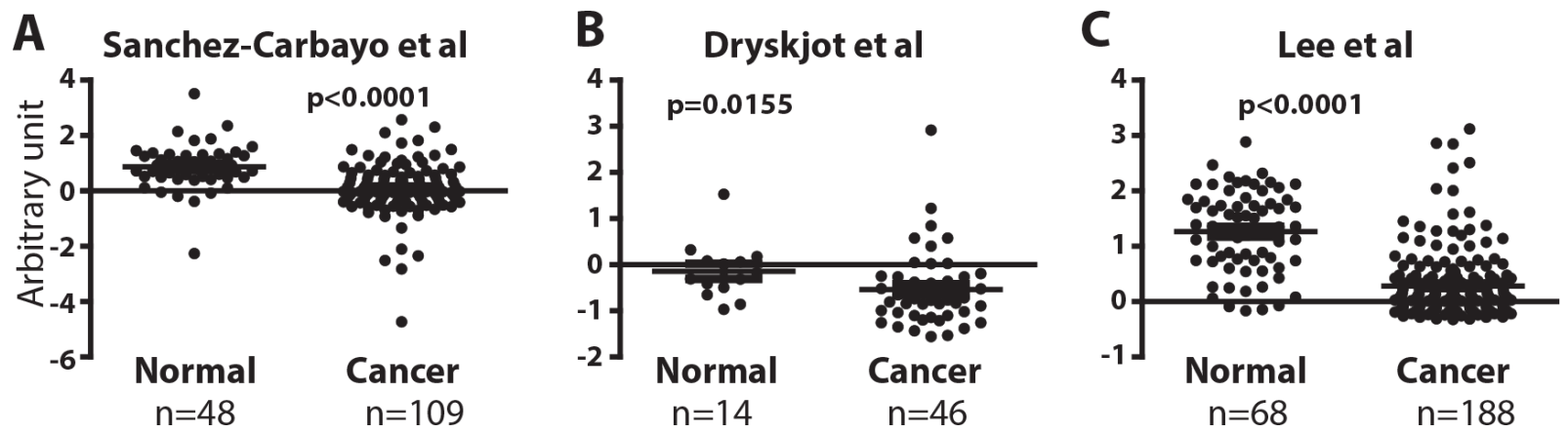

Figure 1: ER $\alpha$ mRNA expression is reduced in bladder tumors. (A, B, and C) ER $\alpha$ expression was compared between normal bladder and BCa tissues in 3 independent databases by Sanchez-Carbayo et al. [33], Dyrskjot et al. [31], and Lee et al. [32]. Differences in distributions were tested by the $t$-test.

\section{Knocking out ER $\alpha$ results in an increased cancer incidence in BBN-induced BCa model}

To investigate the in vivo role of $\mathrm{ER} \alpha$ in $\mathrm{BCa}$ development, we employed cre-loxP strategy to knock out the floxed ER $\alpha$ gene (ER $\alpha$ KO) [34-36]. The breeding scheme for the generation of CMV-ERaKO (Fig. 2A) is presented with CMV-Cre mice crossed with floxed ER $\alpha$. Genotyping results showed that CMV-ER $\alpha \mathrm{KO}$ mice have both Cre and ER $\alpha \mathrm{KO}$ alleles (Fig. 2B). Quantitative-PCR results show ER $\alpha$ mRNA from bladders of CMV-ER $\alpha \mathrm{KO}$ mice was barely detectable compared to WT mice (Fig. 2C). IHC staining results further confirmed that $\mathrm{ER} \alpha$ protein expression is ablated in CMV-ER $\alpha \mathrm{KO}$ bladders (Fig. 2D).

We utilized the pre-carcinogen BBN to induce $\mathrm{BCa}$ as a model to investigate $\mathrm{ER} \alpha$ effect on cancer development. Mice reaching the age of 6 weeks were given $\mathrm{BBN}$ water for 12 weeks, and thereafter given regular water. Female mice were euthanized at 35-weeksold and male mice at 30-weeks-old to determine the $\mathrm{BCa}$ incidence. Initial data analysis showed that $\mathrm{ER} \alpha \mathrm{KO}$ resulted in a higher bladder weight, an indicator of higher bladder cellularity and tumor mass [37] compared to WT bladders (Fig. 2E). Our data in Fig. 2F indicated ER $\alpha$ KO in female mice resulted in a higher $\mathrm{BCa}$ incidence of $81 \%$ compared to $46 \%$ in the WT mice ( $<<0.05$, Fig. $2 \mathrm{G}$ ). Histological analyses showed that these tumors mainly consist of transitional cell carcinomas, and include muscle invasive and non-muscle invasive tissues. Also, ER $\alpha \mathrm{KO}$ males have a higher $\mathrm{BCa}$ incidence, yet the results did not reach a desired statistical difference (ER $\alpha$ KO 85\% 11 out of 13 vs WT $63 \% 17$ out of 27 mice, unpublished data). It is believed there may be other signaling pathways affecting $\mathrm{BCa}$ incidence in males, such as the androgen/ AR pathway $[4,38]$. Thus, a larger mouse sample size may be required in order to determine the male $\mathrm{BCa}$ rate with statistical significance. Overall, our data showed female CMV-ER $\alpha$ KO mice had a higher cancer incidence and tumor mass in the BBN-induced BCa model, suggesting $\mathrm{ER} \alpha$ plays a protective role in female $\mathrm{BCa}$ formation.
In addition to CMV-ER $\alpha \mathrm{KO}$ mice, we generated urothelium specific ER $\alpha \mathrm{KO}$ mice (UPII-ER $\alpha \mathrm{KO}$ ) by breeding floxed $\mathrm{ER} \alpha$ mice with UPII promoter driven Cre transgenic mice [39] (Fig. 3A). Genotyping results show that UPII-ER $\alpha$ KO mice have both Cre and floxed $\mathrm{ER} \alpha$ alleles (Fig. 3B). The ER $\alpha \mathrm{KO}$ allele cannot be detected from genotyping of DNA from tail snips of UPIICre driven knockout mice as Cre recombinase is only expressed in urothelial cells. IHC staining showed ER $\alpha$ protein is also ablated in UPII-ER $\alpha$ KO bladders (Fig. 3C). Female mice were fed with BBN water to induce tumors and then sacrificed at 35 weeks old. Higher bladder weight was found in the UPII-ER $\alpha$ KO mice than in WT mice (Fig. 3D) and histological analysis indicated that UPII$\mathrm{ER} \alpha \mathrm{KO}$ mice have higher $\mathrm{BCa}$ incidence (76\%) than WT mice (40\%) (Fig. 3E), consistent with the phenotypes found in the CMV-ER $\alpha \mathrm{KO}$ mice.

\section{$E R \alpha$ inhibits the malignant transformation of urothelial cells}

In addition to the in vivo $\mathrm{BCa}$ model, we employed SVHUC, a non-malignant urothelial cell line, to study the ER $\alpha$ effect on carcinogen-induced malignant transformation. An earlier report used 3-methylcholanthrene (MCA) to induce malignant transformation of SVHUC cells [40], so we applied the same approach to determine whether expression of ER $\alpha$ can alter the cell transformation ability. SVHUC cells, an $E R \alpha$ negative cell line, were infected with lentiviral PWPI-vector control or PWPI-ER $\alpha$. ER $\alpha$ expression was detected by immunofluoresence staining (Fig. 4A, left panels). We found that cells with ER $\alpha$ expression were less susceptible to MCA-induced malignant transformation than control cells as demonstrated by the soft agar anchorage-independent growth assay (Fig. 4A, middle and right panels). Together, results from our in vivo animal CMV- and UPII-ER $\alpha$ KO BCa models (Figs. 2 and 3) and in vitro malignant transformation tests (Fig. 4A) indicate that $\mathrm{ER} \alpha$ reduces $\mathrm{BCa}$ incidence. 
A<smiles></smiles>

$\mathrm{ERa}^{\mathrm{f} / \mathrm{fl}}$<smiles>[3H][Te][V]</smiles>

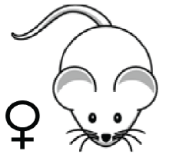

CMV-Cre<smiles>C1CC2CCC(C1)CC2</smiles>

$\mathrm{ERa}^{\mathrm{fl} / \mathrm{+}}$

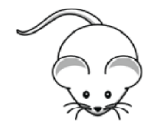
$\mathrm{CMV}-\mathrm{Cre} / \mathrm{ERa}^{-/+}$

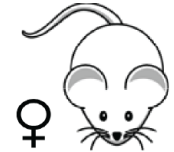<smiles>CC1(C)CC1</smiles><smiles>C1CC2CCC(C1)C2</smiles>

CMV-Cre/ERa ${ }^{-/+}$

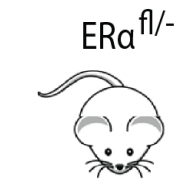

B



C



D
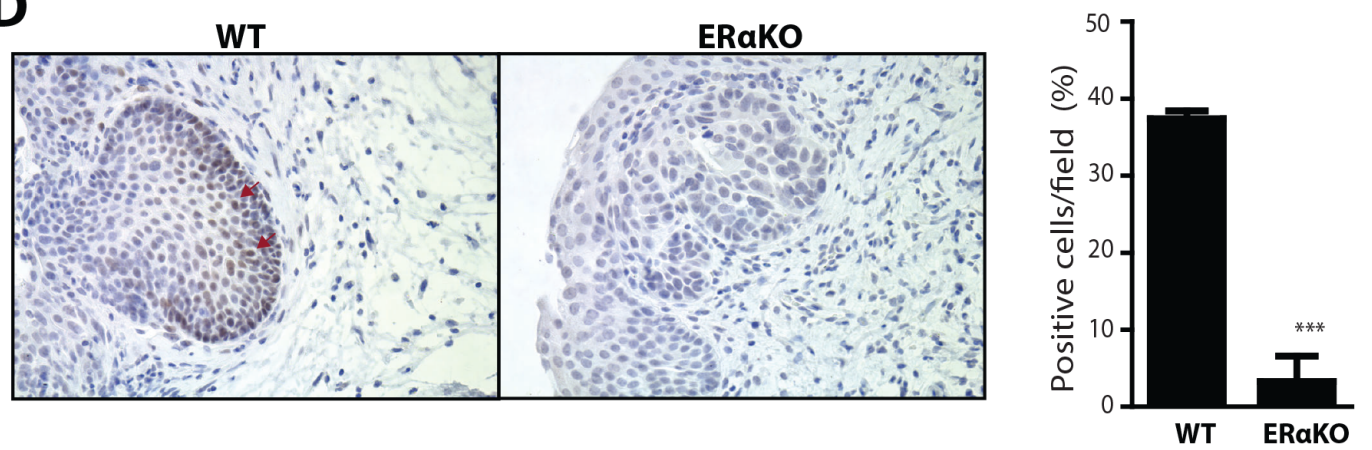

E

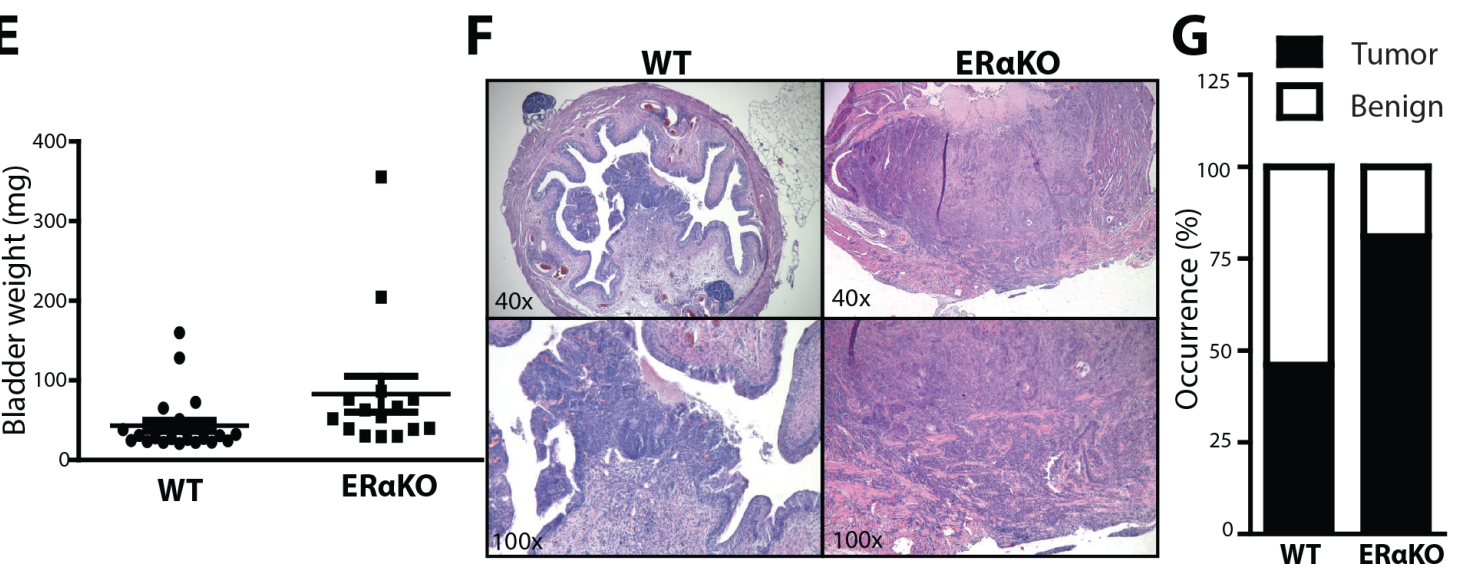

Figure 2: Total ERa knockout increased the cancer incidences in BBN-induced BCa model. (A) ER $\alpha \mathrm{KO}$ mouse breeding scheme. Female mice with Cre coding sequence under the control of human Cytomegalovirus promoter (CMV-Cre) were bred with male floxER $\alpha$ mice $\left(E R \alpha^{\sharp / f 1}\right)$ to generate heterozygous ER $\alpha$ KO mice $\left(\mathrm{CMV}-\mathrm{Cre} / \mathrm{ER} \alpha^{-/+}\right)$. Female CMV-Cre/ER $\alpha^{-/+}$mice were then mated with male $E R \alpha^{\sharp / f l}$ mice to generate WT and ER $\alpha$ KO mice. (B) Tail genomic DNA was isolated and mouse genotypes were identified by PCR using primers flanking ER $\alpha$ exon 3 and Cre. (C) mRNA was collected from whole bladders of female WT and ER $\alpha$ KO mice. Quantitative PCR (qPCR) was used to compare ER $\alpha$ mRNA level. **, p $<0.01$ compared to WT mice by t-test. (D) ER $\alpha$ expression was detected in bladders of female WT and ER $\alpha \mathrm{KO}$ mice by IHC. Red arrows indicate cells expressing ER $\alpha$ protein. Quantifications of ER $\alpha$ positive cells in the mice were shown at right ( $\mathrm{n}=3$ for each). ${ }^{* * *}, \mathrm{p}<0.001$ compared to WT mice by t-test. (E) Bladder weights were compared between WT $(n=28)$ and ER $\alpha$ KO $(n=16)$ female mice at 35 weeks old. $\mathrm{p}=0.0047$ by t-test. (F) Representative images of BBN induced BCa of WT and ER $\alpha \mathrm{KO}$ female mice at 35 weeks old. (G) BBN induced BCa incidence was compared between WT ( $\mathrm{n}=28)$ and $E R \alpha K O(n=16)$ female mice at 35 weeks old. $p=0.03$ by Fisher's exact test. 

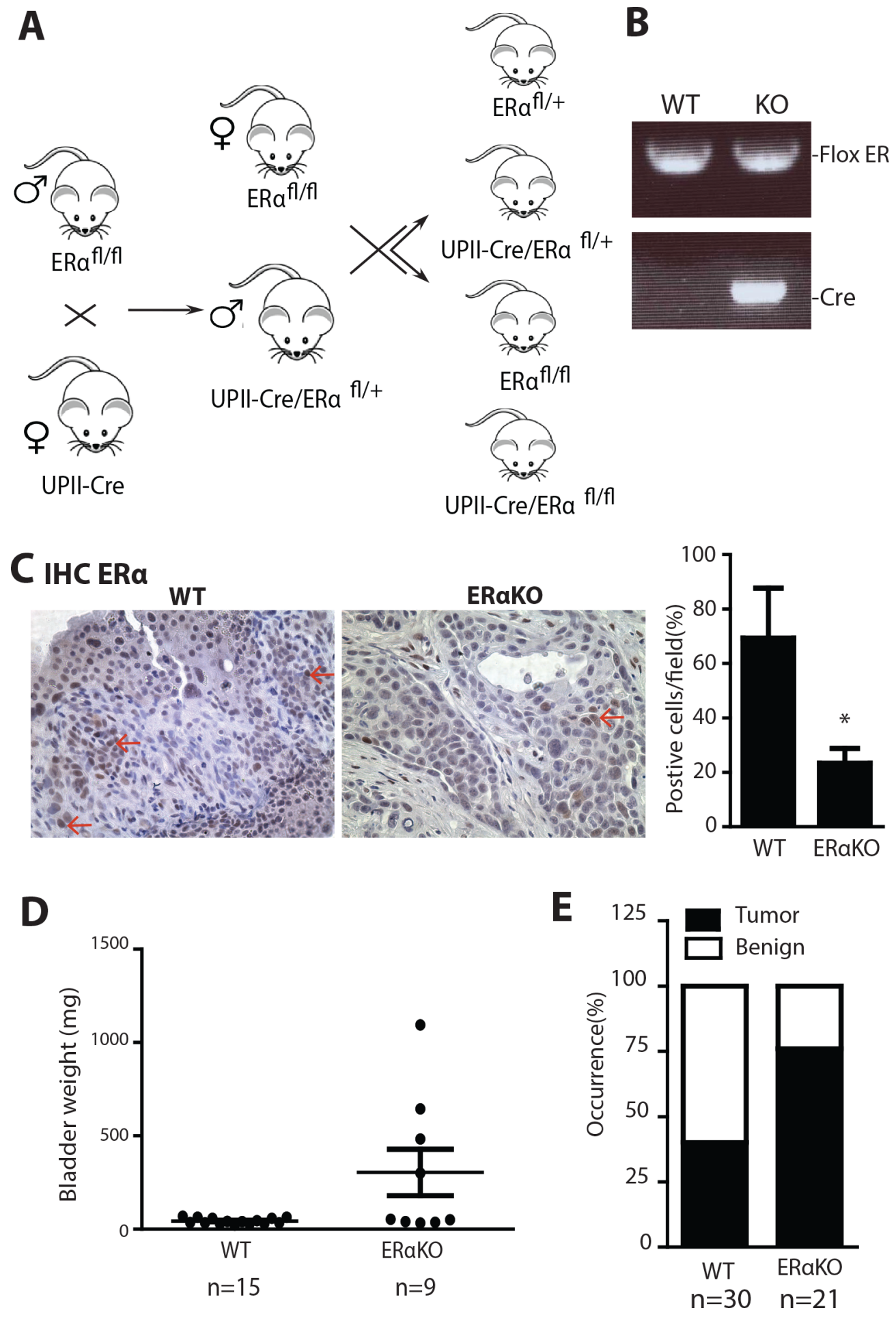

Figure 3: Urothelial specific ERa gene knockout increased the cancer incidences in BBN induced BCa model. (A) Urothelial ER $\alpha$ KO mouse breeding scheme. Female mice with Cre coding sequence under the control of Uropleckin II promoter (UPIICre) were bred with male flox ER $\alpha$ mice $\left(E R \alpha^{\mathrm{f} / / 11}\right)$ to generate heterozygous ER $\alpha \mathrm{KO}$ mice (UPII-Cre/ER $\left.\alpha^{\mathrm{f} / /}\right)$. Male UPII-Cre/ER $\alpha^{\mathrm{f} / /}$ mice were then mated with female ER $\alpha$ fl/fl mice to generate WT and UPII-Cre/ER $\alpha$ KO mice. (B) Tail genomic DNA was isolated for genotyping by PCR using primers flanking ER $\alpha$ exon 3 and Cre primers. (C) ER $\alpha$ protein expression was detected in female bladders of WT and ER $\alpha$ KO mice by immunohistochemistry. Red arrows indicate cells expressing ER $\alpha$ protein. Quantifications of ER $\alpha$ positive cells in the mouse bladder tissues were shown at right $(\mathrm{n}=4$ for each) *, $\mathrm{p}<0.05$ compared to WT mice by t-test. (D) Bladder weights were compared between WT ( $\mathrm{n}=15)$ and UPII-ER $\alpha$ KO $(n=9)$ female mice at 35 weeks old. $\mathrm{p}=0.0120$ by t-test. $(\mathbf{E}) \mathrm{BBN}$ induced BCa incidence was compared between WT $(\mathrm{n}=30)$ and UPII-ER $\alpha K O(n=21)$ female mice at 35 weeks old. $\mathrm{p}=0.0211$ by Fisher's exact test. 


\section{$\mathrm{ER} \alpha$ negatively regulates the $\mathrm{BCa}$ cell growth}

To investigate the ER $\alpha$ effect on $\mathrm{BCa}$ cell growth, $647 \mathrm{v}$, a BCa cell line with endogenous $\mathrm{ER} \alpha$, was infected with lentiviral-shRNA against $\mathrm{ER} \alpha(\operatorname{shER} \alpha)$ or control shRNA against green fluorescent protein (shGFP). ER $\alpha$ was successfully knocked down as shown via examining ER $\alpha$ protein expression as well as its target genes' expression levels (Supplemental Fig. 1). The growth of ER $\alpha$ knockdown or control $647 \mathrm{v}$ cells were compared and results showed that ER $\alpha$ knockdown had a growth advantage over control cells (Fig. 4B), suggesting that expression of $\mathrm{ER} \alpha$ in $\mathrm{BCa}$ cells inhibits their growth. Consistently, expression of $E R \alpha$ via the lentiviral delivery system (PWPI-ER $\alpha$ ) in ER $\alpha$ negative BCa cell lines, UMUC3 and T24 (Fig. 4C and 4D), resulted in growth retardation compared to control cells, again confirming the role of ER $\alpha$ as a suppressor for tumor growth.

Anchorage independent cell growth is a hallmark of higher tumorigenecity or metastatic potential. Equal amounts of $647 \mathrm{v}$ cells with lentiviral shGFP or shER $\alpha$ transduction were suspended in $0.35 \%$ agar and grown for 2 weeks. Our data showed that lower colony numbers were found in cells with ERa expression (Fig. 4E upper panels). Consistently, results showed that UMUC3 cells transduced with PWPI-ER $\alpha$ had lower colony numbers compared to cells transduced with PWPI-vector (lower panels), indicating that expression of ER $\alpha$ reduced anchorage independent $\mathrm{BCa}$ cell growth.

To investigate the ER $\alpha$ effect on in vivo $\mathrm{BCa}$ growth and malignancy, $647 \mathrm{v}$ cells transduced with $\operatorname{shER} \alpha$ or shGFP control were subcutaneously inoculated into nude mice. We found that tumors from $647 \mathrm{v}$-shER $\alpha$ cells were bigger than those from $647 \mathrm{v}$-shGFP control cells (Fig. 4F). This indicates that $\mathrm{ER} \alpha$ plays an inhibitory role and $\mathrm{BCa}$ cells with reduced $\mathrm{ER} \alpha$ are more malignant than $\mathrm{BCa}$ cells with higher ER $\alpha$.

Together, our data demonstrate that ER $\alpha$ acts as a cell growth inhibitor and reduces cell malignancy as demonstrated in both $\mathrm{ER} \alpha$ positive $\mathrm{BCa}$ cells with $\mathrm{ER} \alpha$ knockdown, and in $\mathrm{ER} \alpha$ negative $\mathrm{BCa}$ cells with ectopic $\mathrm{ER} \alpha$ expression using in vitro and in vivo tumor growth assays.

\section{ER $\alpha$ selectively modulates INPP4B expression to control AKT pathway}

Our data from clinical specimen analyses, animal models, and cell malignant transformation have consistently shown that ER $\alpha$ plays a protective role in $\mathrm{BCa}$ development. We were interested in understanding whether ER $\alpha$ regulates or cross-talks with oncogenes or tumor suppressor genes to mediate $\mathrm{BCa}$ development. We selected a panel of oncogene and tumor suppressor genes reported to be important in mediating cancer physiology, especially cell growth, to screen in ER $\alpha$ negative vs. positive cells. From the screening we found that ER $\alpha$ does not regulate p53, ERBB2, or C-MYB mRNA, but selectively controls the expression of INPP4B (Fig. 5A). Also, our results showed that higher ER $\alpha$ expression in $\mathrm{BCa}$ could reduce c-Myc and c-Met expression that may subsequently alter cell growth. The primary test of the change of c-Myc or c-Met by shRNA did not have prominent effect compared to the change of INPP4B to influence $\mathrm{BCa}$ growth (data not shown). Therefore, INPP4B was chosen as ER $\alpha$ downstream effector to be further characterized.

INPP4B was recently demonstrated to have reduced expression in cancer cells and was identified as a tumor suppressor in breast and prostate cancers [27, 28], yet its role in $\mathrm{BCa}$ remains unclear. Although an earlier report showed that INPP4B could be downstream of $E R \alpha$ in breast cancer, there is no functional linkage and no pathophysiological characterization of how $\mathrm{ER} \alpha$ could regulate this pathway to impact any type of cancer development. Our quantitative data showed INPP4B mRNA was induced by $\mathrm{ER} \alpha$ in BCa cells and non-malignant SVHUC cells (Fig. 5B). Consistent with the effect of INPP4B mRNA induction by ER $\alpha$, the INPP4B protein level was also increased in cells with ER $\alpha$ (Fig. 5C).

As ER $\alpha$ is a well-known transcriptional factor [9, 41], we postulated the regulation of INPP4B mRNA is at the transcriptional level. To further dissect how ER $\alpha$ regulates INPP4B expression, $3 \mathrm{~kb}$ of INPP4B gene promoter region was cloned into PGL3 Luciferasereporter vector, INPP4B $(3 \mathrm{~kb})-\mathrm{Luc}$, so that the promoter activity could be monitored by detecting firefly luciferase activity. HEK 293 cells were transfected with INPP4B(3kb)-Luc, vector or ER $\alpha$ expressing plasmids for $24 \mathrm{hr}$, and Luciferase activity results showed cells with ER $\alpha$ expression can upregulate INPP4B promoter activity around 6 fold compared to the control (Fig. 5E). ER $\alpha$ can also activate the INPP4B promoter activity in $\mathrm{BCa}$ UMUC3 cells by 3 fold (Fig. 5E), suggesting increased INPP4B mRNA by ER $\alpha$ is through transcriptional regulation. We then investigated the $3 \mathrm{~kb}$ promoter and found there is a putative non-classic ERE site (located in -2353) that might be bound by ER $\alpha$ and act as an important element to control INPP4B expression. INPP4B-3kb-Luc with deletion of putative ERE was made (mutant INPP4B-3kb-Luc). Fig. 5F showed that the ER $\alpha$ activated INPP4B promoter activity is partially reduced in this mutant reporter, suggesting that ER $\alpha$ can partially regulate INPP4B promoter activity via this non-classic (-2353) ERE. This observation is supported by examining ER $\alpha$ effects on different lengths of the INPP4B promoter (Supplemental Fig. 2A). There is reduced luciferase activity in the $2 \mathrm{~kb}$ length of INPP4B promoter compared to $3 \mathrm{~kb}$ INPP4B promoter suggesting 



$\mathbf{E}$
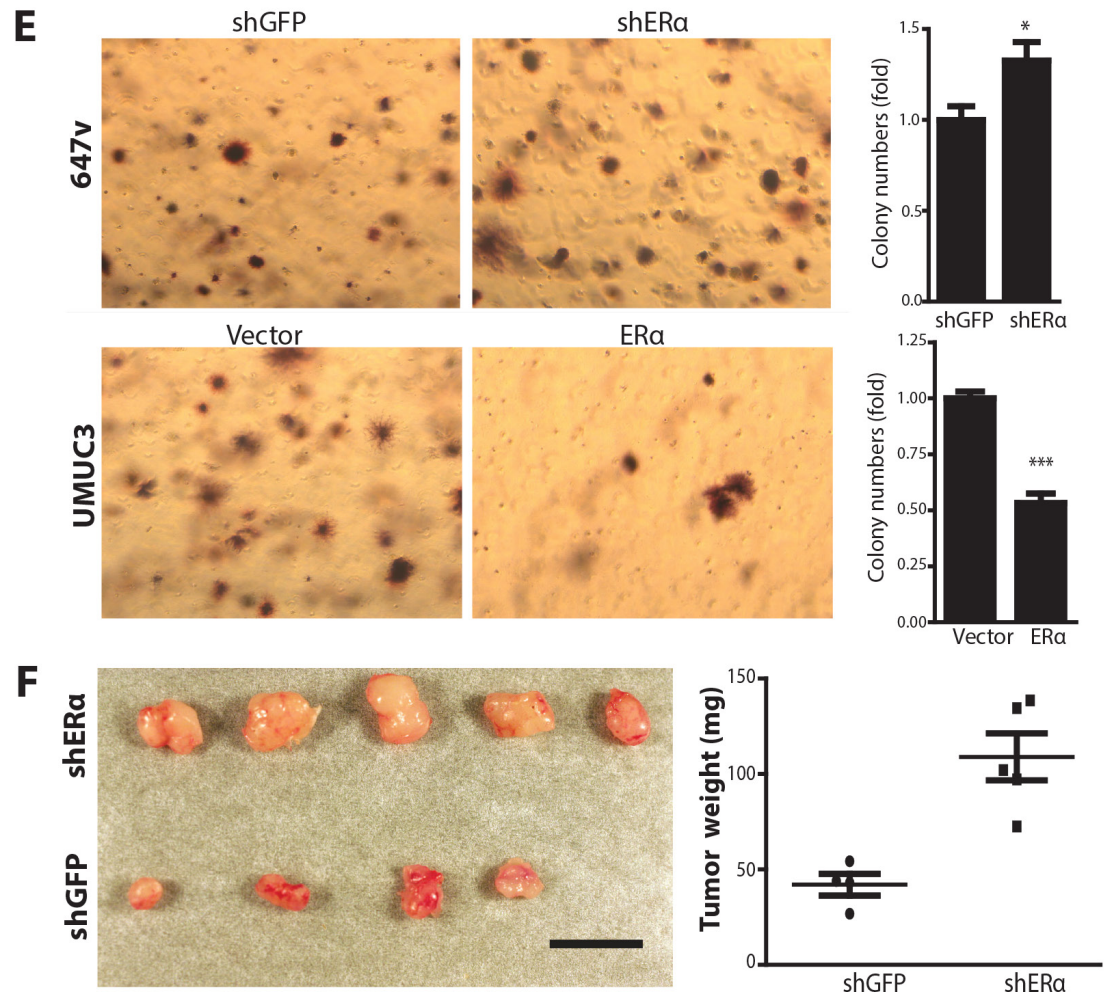

Figure 4: ER $\alpha$ inhibits carcinogen-induced cell malignant transformation and BCa cell growth. (A) ER $\alpha$ expression was detected by antibody (middle 2 panels) and DAPI immunofluorescence staining was used to detect nuclei (left 2 panels) in SVHUC/ER $\alpha^{+}$ and SVHUC/vector cells. Non-malignant SVHUC cells, with or without ER $\alpha$ expression, were subjected to malignant transformation by MCA carcinogen treatment for three cycles and cultured for another six weeks. Soft agar assays (right panels) were performed to analyze cell transformation ability. Quantitative analyses (far right panel) of the colony numbers. ${ }^{* * *}, \mathrm{p}<0.001$ by unpaired $t$-test. (B) MTT assay used to analyze cell growth in 647v (shGFP or shER $\alpha$ ), (C) UMUC3 (vector or ER $\alpha$ ), and (D) T24 (vector or ER $\alpha$ ) cells. ***, p $<0.001$ by Two-way ANOVA test. (E) Anchorage independent cell growth assay of BCa cells, infected with lentiviral shRNA against GFP or $\mathrm{ER} \alpha$ in $647 \mathrm{v}$ cells, and lentoviral ER $\alpha$ or vector control in UMUC3 cells. ${ }^{*}, \mathrm{p}<0.05,{ }^{* * *}, \mathrm{p}<0.001$ compared to control cells by t-test. (F) Knockdown of ER $\alpha$ increases tumor growth in the $647 \mathrm{v}$ xenograft mouse model. Nude mice were injected with $647 \mathrm{v}$ cancer cells expressing shRNA against ER $\alpha$ or control GFP in both flanks. Mice were sacrificed six weeks after cancer cell implantations. Mice injected with $647 \mathrm{v}$ cells with ER $\alpha$ shRNA showed increased tumor weights compared to shGFP control group (left panel). Quantification of tumor weights at right $(\mathrm{p}<0.01$ by $t$-test). 

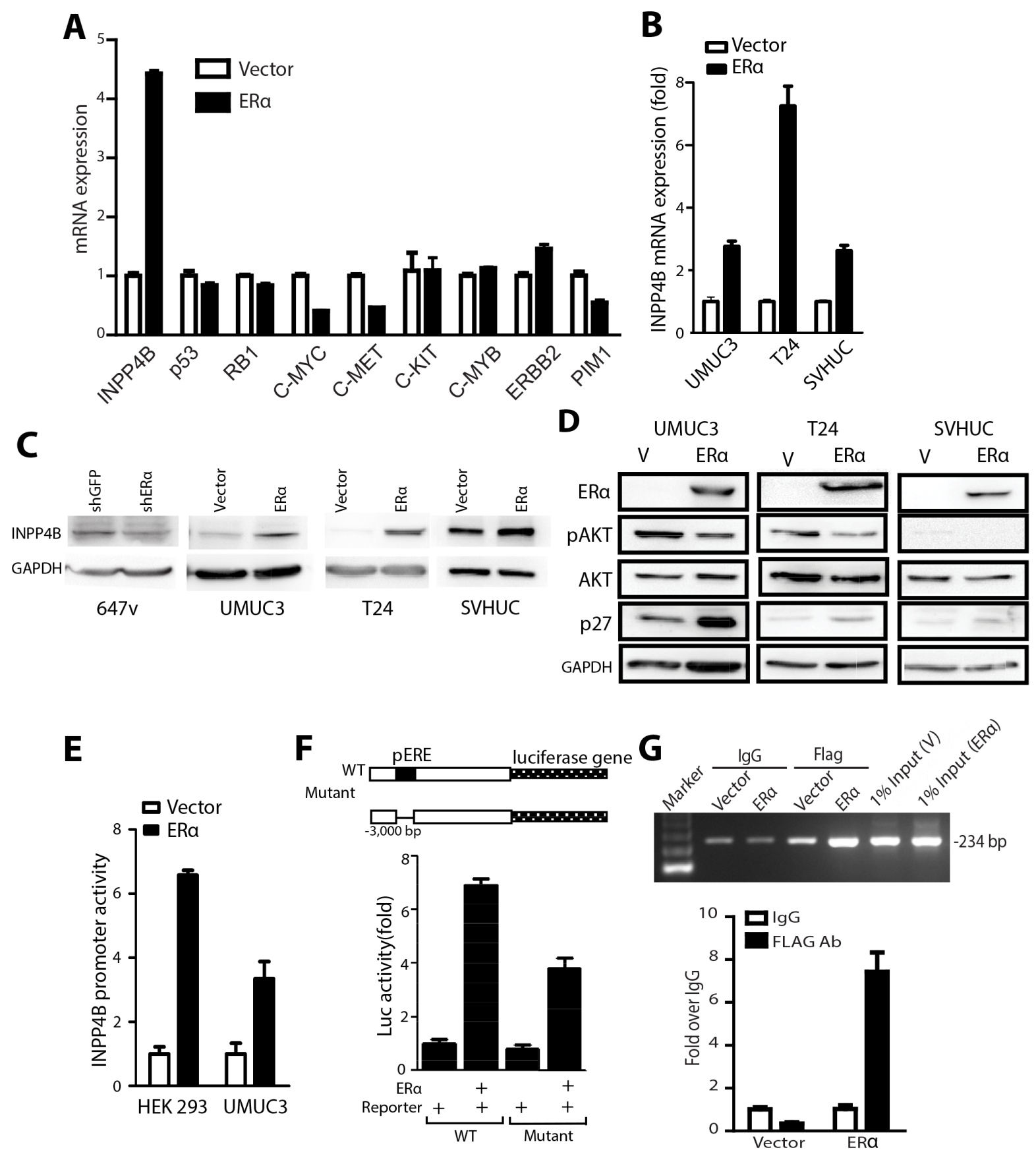

Figure 5: INPP4B expression is up-regulated by ER $\boldsymbol{\alpha}$ in BCa cells. (A) mRNAs were collected from UMUC3 cells transduced with PWPI-vector or PWPI-ER $\alpha$. Q-PCR was performed to examine a panel of tumor suppressor or oncogene genes: INPP4B, p53, RB1, C-MYC, C-MET, C-KIT, C-MYB, BIRC2, and PIM1 expressions. Results were normalized to GAPDH expression. (B) mRNAs were collected from UMUC3, T24, and SVHUC cells transduced with PWPI-vector or PWPI-ER $\alpha$. Expression levels of INPP4B were analyzed by qPCR. Results were normalized to GAPDH expression. (C) Protein lysates were collected from 647v cells transduced with shGFP or shER $\alpha$ or from UMUC3, T24, and SVHUC cells transduced with PWPI-vector or PWPI-ER $\alpha$, followed by western blot detection of INPP4B and GAPDH protein expression. (D) Protein lysates were collected from UMUC3 cells (left panel), T24 cells (middle panel), and SVHUC cells (right panel) transduced with PWPI-vector or PWPI-ER $\alpha$. Western blot was used to detect phosphorylated AKT, total AKT, p27, ER $\alpha$, and GAPDH. (E) 3kb promoter of INPP4B was cloned to PGL3 firefly luciferase plasmid (INPP4B(3kb)-Luc) and transfected with pCDNA-ER $\alpha$ or vector, into HEK 293 and UMUC3 cells. (F) HEK 293 cells were transfected with WT or ERE deletion mutant INPP4B(3kb)-Luc and pCDNA3-ER $\alpha$ for $24 \mathrm{~h}$, and cell lysates were assayed for luciferase activity. Transfection efficiency was normalized to renilla luciferase activity. (G) T24 cells with Vector or FLAG tagged ER $\alpha$ expression was used for CHIP assay. 234 bp was amplified from primers designed flanking the $-2520 \mathrm{bp}$ to $-2287 \mathrm{bp}$ region of INPP4B promoter. FLAG antibodies against FLAG tagged ER $\alpha$ and IgG were used as controls to pull down protein-DNA complex. 1\% input was loaded as positive control. Amplified PCR products were quantified by qPCR and normalized to IgG control shown in lower panel. 
this ERE (located in -2353) could contribute to ER $\alpha$ regulated INPP4B promoter activity. Although no ERE within $2 \mathrm{~kb}$ of INPP4B promoter was observed, there are $\mathrm{C} / \mathrm{EBP}$ binding element that are reported to collaborate with ER $\alpha$ to activate gene expression [42]. Supportively, our chromatin immunoprecipitation (ChIP) assay results showed that ER $\alpha$ can bind to the -2520 to -2287 region of the INPP4B promoter where the putative ERE region is located (Fig. 5G and Supplemental Fig.7), suggesting $\mathrm{ER} \alpha$ binds to the putative ERE region to regulate INPP4B expression. In addition, ChIP data further showed that $\mathrm{ER} \alpha$ could bind to this putative $\mathrm{C} / \mathrm{EBP}$ site (supplemental Fig. 2 and supplemental Fig.7), suggesting ER $\alpha$ could collaborate with other transcription factors for INPP4B promoter regulation.

It was reported that INPP4B could modulate AKT phosphorylation by hydrolyzing $\operatorname{PtdIns}(3,4) \mathrm{P} 2$, which can associate with AKT and lead to AKT phosphorylation [29]. Thus, we examined whether ER $\alpha$ can affect AKT phosphorylation through changing INPP4B expression. Data showed that higher ER $\alpha$ expression reduces AKT phosphorylation at Ser 473, and also the expression of p27, a gene inhibited by AKT, was concomitantly induced by $\mathrm{ER} \alpha$ (Fig. 5D). Although there are other genes downstream of AKT, our data have proved the regulatory pathway of ER $\alpha$ \induced INPP4B囚inhibited AKT囚increased p27 \inhibited BCa cell growth.

\section{Knockdown of INPP4B reverses the ER $\alpha$ - inhibited urothelial malignant transformation and BCa growth}

Decreased INPP4B expression has been reported to contribute to prostate and breast cancer development. To date, there is no report showing the connection of INPP4B with BCa development. We first tested whether INPP4B is a critical factor for the $\mathrm{BCa}$ growth. We introduced shRNA against INPP4B or control shRNA (shLuciferase) into BCa cells, J82 and T24, and examined whether the shRNA can knock down INPP4B and activate downstream effectors, such as AKT phosphorylation. We found that with INPP4B knockdown in the J82 and T24 cells, phosphorylation of AKT at Ser 473 can be increased and the BCa cells have a higher growth rate compared to control cells (Supplemental Fig. 2A and 2B).

As INPP4B is the direct downstream effector of $\mathrm{ER} \alpha$ functions, we were interested in testing whether knockdown of INPP4B can reverse ER $\alpha$ mediated growth inhibition in $\mathrm{BCa}$. We introduced shRNA against INPP4B into ER $\alpha$ expressing BCa cells. The results first showed that $\mathrm{ER} \alpha$ positivity could reduce $\mathrm{BCa}$ cell growth compared to cells not expressing ER $\alpha$ (Fig. 6A and B). When INPP4B was knocked down in the T24 ER $\alpha(+)$ and UMUC3 ER $\alpha(+)$ BCa cells, the ER $\alpha$ mediated cell growth reduction was abolished (Fig. 6A and 6B), suggesting
INPP4B knockdown can reverse ER $\alpha$ mediated inhibition effect on BCa cell growth. Because INPP4B has a baseline expression in the $\mathrm{ER} \alpha(-) \mathrm{BCa}$ cells, it is not surprising to see that INPP4B knockdown in the ER $\alpha(-)$ BCa cells also showed an increased cell growth (Supplemental Fig. 2C).

Furthermore, we tested whether INPP4B knockdown may reverse ER $\alpha$ controlled and inhibited malignant transformation of SVHUC cells. First, ER $\alpha$ expression reduced malignant transformation ability as is reflected by a lower colony number in the soft agar assay, as compared to $\mathrm{ER} \alpha(-)$ SVHUC cells. With INPP4B knockdown in $\mathrm{ER} \alpha(+) \mathrm{SVHUC}$ cells, the colony number was increased to a similar level as $\mathrm{ER} \alpha(-)$ cells (Fig. 6C), suggesting that knockdown of INPP4B in the non-malignant urothelial cells can reverse ER $\alpha$ inhibited malignant transformation. The protein expression levels for INPP4B and ER $\alpha$ in different cells are shown (Fig. 6D).

Importantly and supportively, the ER $\alpha$ inhibited AKT phosphorylation also recovered following INPP4B knockdown, indicating INPP4B is an important ER $\alpha$ downstream effector to regulate AKT phosphorylation (Fig. 6E).

To test whether changes in AKT activation status correlates with the cause of $\mathrm{ER} \alpha$ inhibited cell growth, we examined ER $\alpha$ growth effects on cells with ectopically expressed constitutive active AKT (Supplemental Fig. 4). Data showed that ER $\alpha$-mediated growth inhibition effect can be partially reversed by ectopic expressed constitutive AKT (Lane 4 vs lane 2), suggesting changes of AKT activation status is one of the factors contributing to ER $\alpha$ growth inhibition effect, however, other unidentified factors could be involved and need to be characterized.

\section{Reduced INPP4B expression and increased AKT activity in ERaKO mouse BCa model}

In addition to validating the ER $\alpha$ Dincreased INPP4B囚decreased AKT mechanism in $\mathrm{BCa}$ cells and non-malignant cells, we investigated whether ER $\alpha$ expression can regulate INPP4B expression and AKT activity in the in vivo mouse model. We collected bladder tissues from $\mathrm{BBN}$ treated $\mathrm{WT}$ and $\mathrm{ER} \alpha \mathrm{KO}$ female mice at 35 weeks and detected INPP4B protein and AKT phosphorylation. Ki67, a proliferation marker, was also detected to indicate proliferating cells (Fig. 7, upper panels), and our results indicated cells from ER $\alpha \mathrm{KO}$ mice are highly proliferative as indicated by a high Ki67 staining amount. Importantly, INPP4B protein showed reduced expression in ER $\alpha \mathrm{KO} \mathrm{BCa}$ compared to WT $\mathrm{BCa}$ tissues (Fig. 7 middle panels and Supplemental Fig. 4). Concomitantly, AKT activity was induced in $\mathrm{ER} \alpha \mathrm{KO} \mathrm{BCa}$ compared to WT BCa tissues, indicating ablation of $\mathrm{ER} \alpha$ can enhance AKT activity and this effect could be through the reduced INPP4B (Fig. 7, lower panels). 
A

UMUC3



C



E

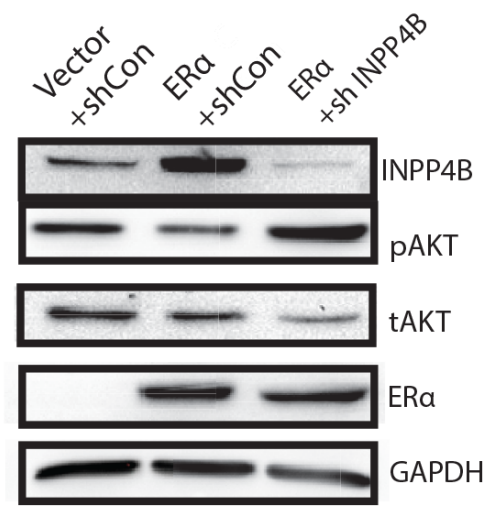

B T24

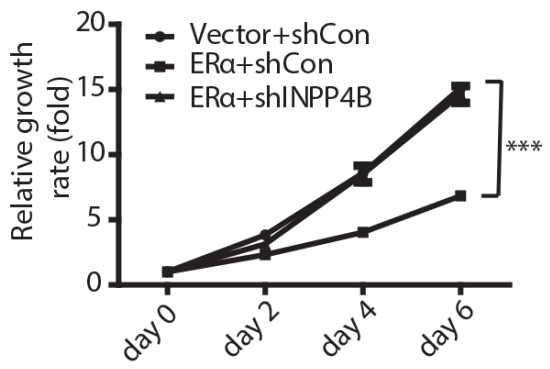

D
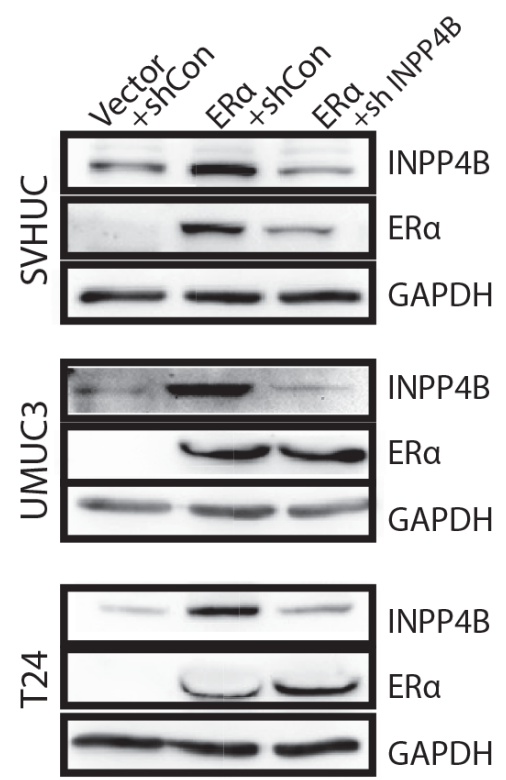

Figure 6: Knocking down INPP4B in BCa cells results in reversal of ERa inhibited BCa cell growth and ERa inhibited malignant transformation of SVHUC cells. UMUC3 (A) and T24 (B) were transduced with lentiviral ER $\alpha$ and/or shINPP4B to investigate the functional connection of $\mathrm{ER} \alpha$ and INPP4B in BCa cell growth. BCa cells were first infected with lentiviral ER $\alpha$ or vector $(E R \alpha(+), v e c)$ and then further infected with lentiviral shINPP4B or sh control. We compared 3 groups of cells: (i) vector/shCon, (ii) ER $\alpha+/$ shCon, or (iii) ER $\alpha+$ /shINPP4B to assay cell growth on Days $0,2,4$ and $6 . * * *, p<0.001$ by Two-way ANOVA test. (C) SVHUC cells were transduced with lentiviral ER $\alpha$ and/or shINPP4b to investigate the functional connection of ER $\alpha$ and INPP4B in bladder cell malignant transformation. SVHUC cells with vector/shCon, $\mathrm{ER} \alpha(+) / \mathrm{shCon}$, or ER $\alpha(+) /$ shINPP4B transduction were subjected to MCA carcinogen treatment. Soft agar assays were performed to analyze malignant transformation ability. Quantitative analysis of the colony numbers of the soft agar assays is shown. ***, $\mathrm{p}<0.001$ by one way ANOVA test. (D) Protein lysates were collected from SVHUC, UMUC3, and T24 cells with lentiviral vector/shCon, $\mathrm{ER} \alpha(+) / \mathrm{shCon}$, and $\mathrm{ER} \alpha(+) / \mathrm{shINPP4B}$ transduction. Immunoblotting was performed with antibodies against ER $\alpha$, INPP4B, and GAPDH. (E) Protein lysates were collected from UMUC3 cells with lentiviral vector/shCon, ER $\alpha(+) / \mathrm{shCon}$, and $\mathrm{ER} \alpha(+) / \mathrm{shINPP} 4 \mathrm{~B}$ transduction. Immunoblotting was performed with antibodies against $\mathrm{ER} \alpha$, INPP4B, phosphorylated AKT (pAKT), total AKT (tAKT), and GAPDH.

\section{Consistent with reduced ERa, INPP4B expression is reduced in human BCa specimens}

We investigated the expression of INPP4B in 129 bladder tumor specimens as well as 87 benign bladder tissues by immunohistochemistry staining. Positive signals were detected predominantly in the cytoplasm of benign/malignant epithelial cells (Fig. 8). Correlations of the expression status with different non-neoplastic and neoplastic bladder tissues are summarized in Table 1 . INPP4B was positive in 76 of $87(87 \% ; 38: 1+, 32: 2+$, and 6: $3+)$ benign urothelial tissues and 80 of $129(62 \%$; 51: $1+, 23: 2+$, and $6: 3+$ ) primary tumors. Overall, INPP4B expression was significantly lower in tumors than in benign urothelium $(\mathrm{P}<0.001)$.

We next evaluated the correlation of INPP4B expression with clinicopathologic profiles available for our patient cohort. There was no significant difference in 

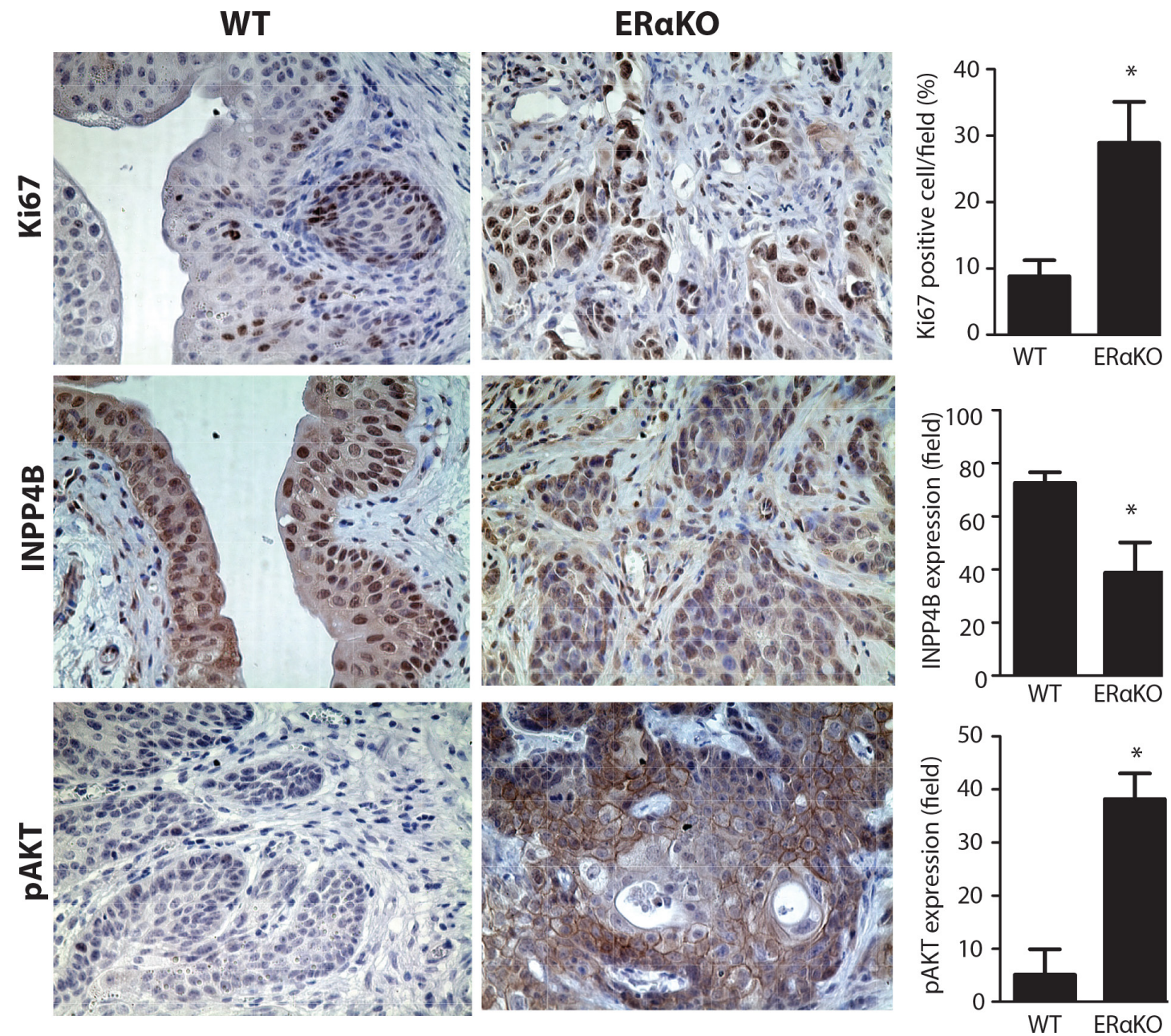

Figure 7: Reduced INPP4B and pAKT expression in BBN treated mouse BCa tissues. Immunohistochemical staining was performed and compared in $\mathrm{BBN}$ induced mouse $\mathrm{BCa}$ from WT and CMV-ER $\alpha \mathrm{KO}$ female mice. IHC was performed with antibodies against Ki67 (upper panels), INPP4B (middle panels), and pAKT (lower panels) ( $\mathrm{n}=3$ for each group), in the bladder tissues from BBN treated WT and CMV-ER $\alpha$ KO female mice at 35 weeks old. *, $\mathrm{p}<0.05$ compared to WT by t-test.

A

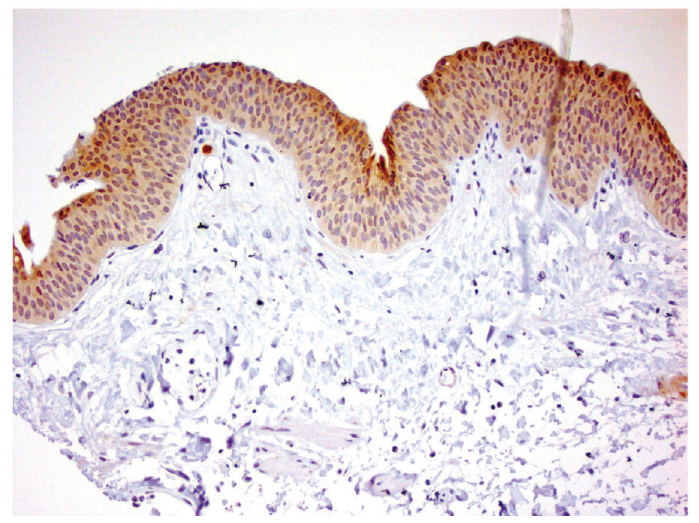

B

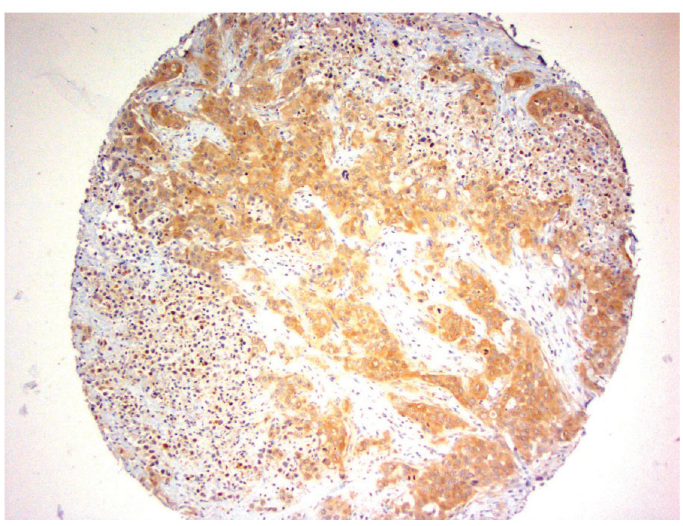

Figure 8: INPP4B immunoreactivity in human bladder tissue. Strong staining in benign urothelium (A) and urothelial tumor (B) is detected. Original magnification in (A) and (B) is $\mathrm{x} 200$. 
Table 1: Expression of INPP4B in bladder tissue microarrays

\begin{tabular}{|c|c|c|c|c|c|c|c|c|}
\hline \multicolumn{6}{|c|}{ INPP4B expression } & \multicolumn{3}{|l|}{ Pvalue } \\
\hline & $\mathbf{N}$ & $\mathbf{0}$ & $1+$ & $2+$ & $3+$ & 0 vs $1+/ 2+/ 3+$ & $0 / 1+$ vs $2+/ 3+$ & $0 / 1+/ 2+$ vs $3+$ \\
\hline Benign & 87 & $11(12.6 \%)$ & $38(43.7 \%)$ & $32(36.8 \%)$ & $6(6.9 \%)$ & \multirow{2}{*}{$<0.001$} & \multirow{2}{*}{0.001} & \multirow{2}{*}{0.551} \\
\hline Tumor & 129 & $49(38.0 \%)$ & $51(39.5 \%)$ & $23(17.8 \%)$ & $6(4.7 \%)$ & & & \\
\hline Low-grade & 52 & $13(25.0 \%)$ & $25(48.1 \%)$ & $13(25.0 \%)$ & $1(1.9 \%)$ & \multirow[t]{2}{*}{0.016} & \multirow[t]{2}{*}{0.391} & \multirow[t]{2}{*}{0.400} \\
\hline High-grade & 77 & $36(46.8 \%)$ & $26(33.8 \%)$ & $10(130 . \%)$ & $5(6.5 \%)$ & & & \\
\hline pTa-1 & 77 & $20(26.0 \%)$ & $34(44.2 \%)$ & $19(24.7 \%)$ & $4(5.2 \%)$ & \multirow{2}{*}{$<0.001$} & \multirow{2}{*}{0.018} & \multirow{2}{*}{1.000} \\
\hline pT2-4 & 52 & $29(55.8 \%)$ & $17(32.7 \%)$ & $4(7.7 \%)$ & $2(3.8 \%)$ & & & \\
\hline ERo(-) & 95 & $41(43.2 \%)$ & $38(40.0 \%)$ & $13(13.7 \%)$ & $3(3.2 \%)$ & \multirow{2}{*}{0.063} & \multirow{2}{*}{0.008} & \multirow{2}{*}{0.340} \\
\hline $\operatorname{ERa}(+)$ & 34 & $8(23.5 \%)$ & $13(38.2 \%)$ & $10(29.4 \%)$ & $3(8.8 \%)$ & & & \\
\hline
\end{tabular}

INPP4B expression pattern between male vs. female tumors. Thirty-nine out of $52(75 \%)$ low-grade tumors were INPP4B positive, whereas 41 out of $77(53 \%)$ high grade carcinomas were INPP4B-positive $(\mathrm{P}=0.016)$. Similarly, 57 of 77 (74\%) non muscle invasive tumors expressed INPP4B, compared with 23 of $52(44 \%)$ muscle invasive tumors $(\mathrm{P}<0.001)$. There were also correlations between statuses of $\mathrm{ER} \alpha$ and INPP4B in tumors $(0 / 1+$ vs. $2+/ 3+, \mathrm{P}=0.008)$.

Although in one earlier report, INPP4B could be colocalized with ER $\alpha$ in luminal cells of breast cancer, yet there was no functional linkage and no pathophysiological characterization how ER $\alpha$ could regulate this INPP4B pathway to impact any type of cancer development. Especially, INPP4B suppressor function is in contrast with $\mathrm{ER} \alpha$ tumor promoting roles in breast cancer. Our work is the first report to show pathophysiological characterization of how ER $\alpha$ interplays with INPP4B to inhibit bladder malignant transformation and cancer growth in vivo as well as in vitro.

Together, we provide evidence from multiple in vitro cell studies and in vivo cre-loxP ERaKO tumor models, as well as human $\mathrm{BCa}$ tissue data to prove ER $\alpha$ plays a protective role in $\mathrm{BCa}$ initiation and growth via modulating the INPP4B/Akt pathway.

\section{DISCUSSION}

\section{Early studies about estrogen effects in BCa development}

Earlier reports showed that ER $\alpha$ promotes cancer development in breast, ovarian and endometrium [43-46]. In contrast, ER $\alpha$ inhibition of cancer incidence could be observed in liver and colon cancers, where males have higher cancer incidence than females [47-49]. How estrogen and ERs regulate $\mathrm{BCa}$ development remains to be further characterized. There has been a report using synthetic estrogen or $17 \beta$-estradiol (E2) to treat male rats in $\mathrm{BBN}$ induced $\mathrm{BCa}$ models, and results showed that male rats receiving estrogen have lower $\mathrm{BCa}$ incidence compared to vehicle treated rats [50]. Although the results suggested that rats with estrogen exposure have a reduced $\mathrm{BCa}$ incidence, some concerns were raised from these studies. First, the supplementation of estrogen to the rats was not within physiological range. Second, the super physiological doses of estrogen could inhibit the production of testicular androgens in male rats. In addition, other hormone levels including progesterone, Folliclestimulating hormone and Luteinizing hormone, could be dramatically altered in these estrogen over-exposed animals. Other prior reports also showed controversial roles of ERs in $\mathrm{BCa}$ growth [16, 51].

\section{Other supportive reports as well as our evidences about the protective roles of $\mathrm{ER} \alpha$ in $\mathrm{BCa}$}

Therefore, in order to specifically characterize ER $\alpha$ effect on $\mathrm{BCa}$ development without the compromised phenotypes from altered hormonal profiles, the mouse $\mathrm{BCa}$ models with cre-loxP ER $\alpha$ gene knockout (CMV$\mathrm{ER} \alpha \mathrm{KO}$ and UPII-ER $\alpha \mathrm{KO}$ ) were chosen for our study. In this study, we provide evidence from in vitro cell lines studies and in vivo mouse models to demonstrate that $\mathrm{ER} \alpha$ inhibited $\mathrm{BCa}$ incidence and growth. In addition to our results, other studies also imply that reduced ER $\alpha$ signaling may be associated with $\mathrm{BCa}$ incidence. For example, arsenic exposure and schistosomiasis infections are linked to increased $\mathrm{BCa}$ risk and both events have 
been associated with reduced ER $\alpha$ signaling $[52,53]$. Furthermore, people who carry the ER $\alpha-397 T$ allele, have a higher susceptibility to BCa [54], implying ER $\alpha$ signaling is associated with $\mathrm{BCa}$ incidence. Together, $\mathrm{ER} \alpha$ inhibition effects on both malignant transformation and $\mathrm{BCa}$ cell growth indicate that urothelium ER $\alpha$ expression plays protective roles against $\mathrm{BCa}$ development, consistent with in vivo mouse data in which $\mathrm{ER \alpha KO}$ mice have a higher $\mathrm{BCa}$ incidence. Together, there are other supportive reports as well as our data demonstrating the protective roles of $\mathrm{ER} \alpha$ in $\mathrm{BCa}$.

\section{Differential roles of $\mathrm{ER} \alpha$ and $\mathrm{ER} \beta$ in $\mathrm{BCa}$}

The sexual difference of $\mathrm{BCa}$ occurrence suggests that estrogen and its receptors may play roles in $\mathrm{BCa}$ development. However, there are two major types of estrogen receptors, ER $\alpha$ and ER $\beta$, to mediate estrogen effects. Treatments with selective ER modulators, including raloxifene and tamoxifen, have been shown to reduce $\mathrm{BCa}$ growth [55]. Our recent results with cre-loxP ER $\beta K O$ show inhibition of mouse $\mathrm{BCa}$ development, suggesting ER $\beta$ promotes $\mathrm{BCa}$ development. Mechanism dissection found that targeting ER $\beta$ suppressed the expression of minichromosome maintenance complex component 5 (MCM5), a DNA replication licensing factor that is involved in tumor cell growth. Restoring MCM5 expression can partially reverse ER $\beta$ knockdownmediated growth reduction. Supportively, treating cells with the ER $\beta$-specific antagonist, 4-[2-Phenyl-5, 7-bis(trifluoromethyl) pyrazolo[1,5-a]pyrimidin-3-yl] phenol (PHTPP), reduced BCa cell growth and invasion, as well as MCM5 expression [56]. The present study showed that $\mathrm{ER} \alpha$ plays a protective role in $\mathrm{BCa}$ via upregulation of INPP4B and inhibition of Akt. In addition, human $\mathrm{BCa}$ tissue $\mathrm{ER} \alpha$ and $\mathrm{ER} \beta$ staining results conclude that loss of ER $\alpha$ was strongly associated with higher grade/more invasive tumours, whereas ER $\beta$ expression was increased in high-grade/invasive tumours and its presence predicted a worse prognosis [14]. Together, our data support the concept that ER $\alpha$ and ERß could play differential roles in $\mathrm{BCa}$ development $[56,57]$.

\section{ER $\alpha$ expression is reduced in cancer tissues}

We observed less ER $\alpha$ mRNA level in the cancer tissues from various stages compared to normal tissues either from histologically normal-looking surrounding or normal bladder tissues. Although the magnitude of change between the non-malignant and $\mathrm{BCa}$ is not huge, it is still meaningful due to statistical significance and considering the potential variation of human tissue analysis. Because of this observation and the $\mathrm{BCa}$ incidence difference of male to female (3.5:1), we hypothesized ER $\alpha$ may play a protective role in $\mathrm{BCa}$ initiation and examined whether altered $\mathrm{ER} \alpha$ expression can influence $\mathrm{BCa}$ development using in vitro cell studies and in vivo animal models. The mechanism studies showed that ER $\alpha$ could function via regulating of INPP4B/inhibited Akt pathway to control BCa development.

Among 3 data sets we analyzed, we observed consistent $\mathrm{ER} \alpha$ mRNA reduction in $\mathrm{BCa}$. However, there is no consistent change of INPP4B mRNA among these $3 \mathrm{BCa}$ databases. It is not surprisingly to see the somewhat different clinical data analyses, which may involve the different platforms used (Affymetrix or Illumina), probes designed, or tissue preparation (biopsies vs. whole tissues) [58]. Importantly and notably, INPP4B has been demonstrated as a tumor suppressor in different cancer types such as prostate and breast [27, 30, 59], consistent with what we have observed for BCa using IHC staining of the INPP4B protein (Fig. 8). The change of INPP4B mRNA in $\mathrm{BCa}$ tissues merits more investigations. Overall, we observed the correlated ER $\alpha$ and INPP4B reduction at protein levels.

\section{Estrogen exposure inhibits bladder cancer incidence and management of ER $\alpha$ signal pathway may be a potential agent for preventing bladder cancer.}

There are also reports suggesting that estrogen inhibits $\mathrm{BCa}$ incidence. Postmenopausal women have a higher risk of $\mathrm{BCa}$ than premenopausal women [60], and women who reach menopause at a younger age have a significantly increased risk of $\mathrm{BCa}$ [61-63], supporting the concept that estrogens might inhibit $\mathrm{BCa}$ incidence. Additional clinical studies also supported that higher frequencies of estrogen exposure might lead to less $\mathrm{BCa}$ incidence. For example, parous women (during pregnancy, estradiol increases) [61-65] and those who used estrogen and progestin for hormonal therapy $[63,64]$ have a lower risk for $\mathrm{BCa}$ formation, again suggesting high estrogen exposure decreases $\mathrm{BCa}$ risk. These observations are consistent with what we found that estrogen can enhance $\mathrm{ER} \alpha$ effect on inhibiting $\mathrm{BCa}$ growth (Supplemental Fig. 6A). The concept is further supported with the observation that ER $\alpha$ mutants (Y537S and D538G), which have mutations in the ligand binding domain and have been demonstrated to maintain transcriptional activity [66, 67] in the absence of estrogen, showed dramatic growth inhibition effect on BCa cells (Supplemental Fig. 6B). Those results imply that higher frequency of estrogen exposure may protect women from $\mathrm{BCa}$ occurrence, suggesting estrogens play protective roles in $\mathrm{BCa}$ initiation and might serve as therapeutic agents.

\section{Potential applications of Akt inhibitors, ER $\alpha$ selective agonist and downstream pathways for BCa therapy}

Our studies proved that $\mathrm{ER} \alpha$ can up-regulate INPP4B expression and concomitantly reduce AKT 
phosphorylation status and activity. An earlier report showed AKT activity is increased in $\mathrm{BCa}$ and has been correlated to BCa stage [68]. Furthermore, inhibitors against AKT activity have been developed for use in pre-clinical trials [69]. The effect of AKT inhibitors on cell growth was also evaluated in a variety of cancers $[70,71]$. Our ER $\alpha$-INPP4B mechanism results support that AKT inhibitors may be applied to treat BCa. In addition, our data proved that $\mathrm{ER} \alpha$ inhibits cell transformation and cancer cell growth. It is possible that propylpyrazoletriol (PPT), a selective agonist for $\mathrm{ER} \alpha$, may be applied to treat $\mathrm{BCa}$ patients and to inhibit BCa cells growth. From the screening to examine which oncogenes or tumor suppressors can be altered by $\mathrm{ER} \alpha$, we found that $\mathrm{ER} \alpha$ expression in $\mathrm{BCa}$ can reduce c-Myc and c-Met expression, which could subsequently alter cell growth. This might provide an alternative pathway for ER $\alpha$ to regulate cell growth.

Together, our study has provided multiple evidences to demonstrate $\mathrm{ER} \alpha$ inhibition role in $\mathrm{BCa}$ development both in vitro and in vivo by modulating the INPP4B/Akt pathway, and suggest that the ER $\alpha$ agonist, PPT, or AKT inhibitors could be used as therapeutic agents in the future to control BCa development.

\section{ACKNOWLEDGEMENT}

This work was partially supported by the URMC Urology Fund, and 5 UL1 TR000042-09. The current address for Mesut Muyan is Department of Biological Sciences, METU, Ankara, Turkey.

\section{MATERIALS AND METHODS}

\section{Generation and genotyping of CMV-Cre/ERa-/-

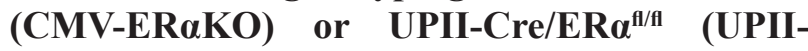 ERaKO) mice}

The ER $\alpha^{\mathrm{f} / \mathrm{fl}}$ mouse with lox sequence flanking exon 3 of ER $\alpha$ allele (floxed ER $\alpha$ ) was produced as previously described [36, 72]. CMV-ER $\alpha \mathrm{KO}$ mice were generated by crossing $\mathrm{ER} \alpha^{\mathrm{f} / \mathrm{fl}}$ male mice with $\mathrm{CMV}-\mathrm{Cre}$ transgenic female mice (Jackson Laboratories, Bar Harbor, ME). UPII-ER $\alpha \mathrm{KO}$ mice were generated by crossing $E R \alpha^{\mathbf{f} / \mathrm{fl}}$ female mice with UPII-Cre transgenic male mice (obtained from Dr. Xue-Ru Wu, NYU). The sizes of the wild type $\mathrm{ER} \alpha$ allele, floxed $\mathrm{ER} \alpha$ allele, and $\mathrm{ER} \alpha \mathrm{KO}$ allele were 741, 881, and 223 bps, respectively. To identify Cre recombinase bearing transgenic mice, primer sequences located in the Cre coding regions were used. The PCR product of the Cre fragment was 411 bps. ER $\alpha \mathrm{KO}$ allele can be detected from genotyping of DNA from tail snip in CMV-Cre driven knockout but cannot be detected in UPIICre driven knockout.

\section{Bladder Samples for ESR1 mRNA analysis}

In Dyrskjot bladder studies, there are 14 normal biopsies and 46 cancer samples where cancer tissues are biopsies from 28 superficial bladder tumors (Ta and T1) (13 tumors with surrounding CIS and 15 without surrounding CIS) and 13 invasive carcinoma (T2 to T4) and biopsies from 5 CIS patients. In Lee bladder studies, there are 68 normal and 188 cancer tissues. Normal tissues are from fifty-eight samples of histologically normal-looking surrounding tissues from the patients with urothelial carcinoma and 10 normal bladder mucosae from patients with benign diseases. Cancer tissues are from 126 samples of superficial bladder tumors (Ta and $\mathrm{T} 1$, recurrent and not recurrent) and 62 invasive carcinoma (T2 to T4). In Sanchez-Carbayo Bladder studies, there are 48 normal urothelium and 109 cancer samples. For cancer tissues, 28 samples of superficial bladder tumors (Ta-Tis-T1) and 81 invasive carcinoma tissues (T2-T4).

\section{Inducing $\mathrm{BCa}$ with $\mathrm{BBN}$ in drinking water}

Both WT and ER $\alpha$ KO female mice in C57BL/6 background were supplied with sterile distilled water containing $0.05 \%$ BBN (TCI America) at 6 weeks old for 12 weeks and thereafter with normal drinking water until the mice were sacrificed [4].

\section{Immunoblotting and Immunohistochemical staining (IHC)}

$\mathrm{BCa}$ cells were lysed for Western blotting and proteins were detected using the antibodies, GAPDH (Santa Cruz 32233), P-Ser473 AKT (Cell Signaling 4060), INPP4B (Santa Cruz 12318), Total AKT (Cell Signaling 9272), ER $\alpha$ (produced in our lab, SC1-1), and p27 (Santa Cruz 528). Tissue fixation and sectioning were processed as previously described $[36,73]$. Tissue sections were incubated with ER $\alpha$ antibodies (Santa Cruz, MC-20), P-Ser473 AKT (Cell Signaling 4060), INPP4B (Abcam EPR3108), Ki67 (Novocastra).

\section{RNA isolation and real time PCR}

Detailed RNA isolation and real time PCR was as previously described $[36,72]$.

\section{Cell Culture and anchorage independent growth assay}

UMUC3, 647v, and T24 cells were purchased from ATCC and cultured in DMEM with $10 \%$ fetal bovine serum. SVHUC cells were purchased from ATCC and 
maintained in F12-K with $10 \%$ fetal bovine serum. Anchorage independent cell growth was performed by plating $1 \%$ soft agar on the bottom of plates, allowing the agar to solidify and then seeding the suspending cells in $0.35 \%$ of soft agar in DMEM. Cells were grown in soft agar for two weeks and stained with $0.2 \mu \mathrm{g} / \mathrm{ml}$ Iodonitrotetrazolium chloride (Sigma-Aldrich) for $20 \mathrm{hr}$ to indicate live cells. Live colonies were counted and compared between cells with and without ER $\alpha$ expression.

\section{Malignant transformation assay}

Cell transformation protocol was followed according to Reznikoff et al. [40]. Briefly, $1 \times 10^{5}$ of SVHUC cells cultured in $10-\mathrm{cm}$ dishes were exposed to $5 \mu \mathrm{g} / \mathrm{ml}$ 3-methylcholanthrene (MCA) for $48 \mathrm{hr}$ and then cultured for about 10 days until cells reached confluence followed by subculturing cells using a $1 / 3$ split. The treatment cycle was repeated two more times. The recovered cells were cultured for 6 weeks by regular passage, and $2 \times 10^{5}$ cells were used for soft agar assay to determine malignant transformation.

\section{Lentiviral vectors construction and virus production}

The cDNA encoding ER $\alpha$ was cloned into PWPI lentiviral vector that was constructed with SV40-puro for cell selection purpose (PWPI-ER $\alpha$ ). The short hairpin RNA (shRNA) expressing lentiviral vector against GFP (PLKO.1-puro-shGFP) and PLKO.1 hygro vector were obtained from Addgene. The shRNA against ER $\alpha$ (PLKO.1-puro-shER $\alpha$ ) and control (PLKO.1-hygroINPP4B scramble) and INPP4B (PLKO.1-hygro-INPP4B) were constructed with target sequence according to Addgene's pLKO. 1 protocol. The target sequence for ER $\alpha$ was 5'-GTACCAATGACAAGGGAAGT-3', for scramble INPP4B was 5'-GAATTATACCGTCAACTCTAA-3' and for INPP4B was 5'-CCCTTCACATTAAAGAAGATT-3'. Lentiviral particles were generated and transduced into cells.

\section{INPP4B (3kb)-Luciferase and ERE mutant INPP4B(3kb)-Luciferase plasmid construction}

A 3000-base pair fragment of the 5'-flanking region of the INPP4B gene was amplified by PCR from T24 genomic DNA and ligated into pGL3-Basic Vector (Promega, WI), designed as INPP4B(3kb)Luc. The region is defined as promoter from Ensembl project [74]. The oligonucleotides used for PCR is 5'CCGGGCTAGCATGACTGGGGGAAGACAAAAG-3' (-3000 to -2987) with NheI restriction enzyme site and 5'CCGGCTCGAGCAGGTGCCACCTGGCGGCTCTCT
-3 ' (-1 to -12$)$ with XhoI restriction enzyme site. The ERE mutant INPP4B(3kb)-Luc has same promoter region with deletion from -2353 to $-2366 \mathrm{bp}$.

\section{Luciferase reporter assay}

Cells were transfected with empty vector (pcDNA3) or ER $\alpha$ expressing vector (pcDNA3-ER $\alpha$ ) and PGL3-3kbINPP4B promoter driven luciferase expressing vector and SV40 driven renilla expressing vector as control for $24 \mathrm{hrs}$ followed by lysing cells with lysis buffer and assayed according to manufacturer's instructions (Dual-Luciferase Reporter Assay System, Promega).

\section{Immunohistochemical staining of INPP4B in human bladder tissue microarray}

We retrieved 129 bladder specimens obtained from transurethral resections or cystectomy performed at the Johns Hopkins Hospital. All the sections were reviewed for confirmation of original diagnoses, according to the 2004 World Health Organization/International Society of Urological Pathology classification system for urothelial neoplasms [75], by an urologic pathologist (G.J.N.). Appropriate approval from the Institutional Review Board was obtained prior to construction and use of the tissue microarray (TMA). Bladder TMAs were constructed from formalin fixed paraffin embedded specimens (129 tumor tissues and 87 benign appearing tissues from bladders of patients with tumors), as previously described [14]. These patients included 98 men and 31 women, with a mean age of 65.7 years (range: $26-89$ years) at the time of surgery and a mean follow-up of 32.7 months (range: 2-164 months) post surgery. The primary tumors included 12 papillary urothelial neoplasms of low malignant potential (PUNLMPs), 40 non-invasive (pTa) low-grade urothelial carcinomas, 26 non-muscle-invasive $(\leq \mathrm{pT} 1)$ high-grade urothelial carcinomas, and 51 muscle-invasive $(\geq$ pT2) high-grade urothelial carcinomas. All 51 patients with muscle-invasive tumors underwent cystectomy. None of the patients had received therapy with radiation or anticancer drugs pre-operatively, except for 14 cases with intravesical bacillus Calmette-Guérin treatment prior to radical cystectomy. All of these 129 cases were included in our prior study analyzing 188 cases for the expression of $\operatorname{ER} \alpha$ [14].

Immunohistochemical staining was performed, using the primary antibody to INPP4B (HPA037682, 1:150 dilution, Sigma-Aldrich). All the stains were manually scored by an experienced and certified pathologist (H.M.) blinded to patient identity. The German Immunoreactive Score was calculated by multiplying the percentage of immunoreactive cells $(0 \%=0 ; 1-10 \%=1 ; 11-50 \%=2$; $51-80 \%=3 ; 81-100 \%=4)$ by staining intensity 
(negative $=0 ;$ weak $=1 ;$ moderate $=2 ;$ strong $=3$ ). The immunohistochemical scores (ranging from 0-12) were considered negative $(0 ; 0-1)$, weakly positive $(1+; 2-4)$, moderately positive $(2+; 6-8)$, and strongly positive $(3+$; 9-12) for INPP4B expression. The Fisher's exact test was used to evaluate the association between categorized variables.

\section{Statistics}

Differences in cancer incidence between BBN treated WT and ER $\alpha \mathrm{KO}$ mouse studies were analyzed by Fisher's exact test. Student's t-test was used to test the differences of mRNA level and colony formation ability between lentiviral vector and lentiviral ER $\alpha$ transduced cells.

\section{Disclosure}

The authors have nothing to disclose.

\section{REFERENCES}

1. Siegel R, Naishadham D and Jemal A. Cancer statistics, 2012. CA Cancer J Clin. 2012; 62(1):10-29.

2. Sievert KD, Amend B, Nagele U, Schilling D, Bedke J, Horstmann M, Hennenlotter J, Kruck S and Stenzl A. Economic aspects of bladder cancer: what are the benefits and costs? World J Urol. 2009; 27(3):295-300.

3. Scelo $G$ and Brennan P. The epidemiology of bladder and kidney cancer. Nat Clin Pract Urol. 2007; 4(4):205-217.

4. Miyamoto $H$, Yang Z, Chen YT, Ishiguro H, Uemura $H$, Kubota Y, Nagashima Y, Chang YJ, Hu YC, Tsai MY, Yeh S, Messing EM and Chang C. Promotion of bladder cancer development and progression by androgen receptor signals. J Natl Cancer Inst. 2007; 99(7):558-568.

5. Lindberg MK, Weihua Z, Andersson N, Moverare S, Gao H, Vidal O, Erlandsson M, Windahl S, Andersson G, Lubahn DB, Carlsten H, Dahlman-Wright K, Gustafsson JA and Ohlsson C. Estrogen receptor specificity for the effects of estrogen in ovariectomized mice. J Endocrinol. 2002; 174(2):167-178.

6. Couse JF, Dixon D, Yates M, Moore AB, Ma L, Maas R and Korach KS. Estrogen receptor-alpha knockout mice exhibit resistance to the developmental effects of neonatal diethylstilbestrol exposure on the female reproductive tract. Dev Biol. 2001; 238(2):224-238.

7. Spencer-Segal JL, Tsuda MC, Mattei L, Waters EM, Romeo RD, Milner TA, McEwen BS and Ogawa S. Estradiol acts via estrogen receptors alpha and beta on pathways important for synaptic plasticity in the mouse hippocampal formation. Neuroscience. 2011; 202:131-146.

8. Hill L, Jeganathan V, Chinnasamy P, Grimaldi C and Diamond B. Differential roles of estrogen receptors alpha and beta in control of B-cell maturation and selection. Mol Med. 2010; 17(3-4):211-220.

9. Bjornstrom L and Sjoberg M. Mechanisms of estrogen receptor signaling: convergence of genomic and nongenomic actions on target genes. Mol Endocrinol. 2005; 19(4):833-842.

10. Lin BC, Suzawa M, Blind RD, Tobias SC, Bulun SE, Scanlan TS and Ingraham HA. Stimulating the GPR30 estrogen receptor with a novel tamoxifen analogue activates SF-1 and promotes endometrial cell proliferation. Cancer Res. 2009; 69(13):5415-5423.

11. Ignatov T, Eggemann H, Semczuk A, Smith B, Bischoff J, Roessner A, Costa SD, Kalinski T and Ignatov A. Role of GPR30 in endometrial pathology after tamoxifen for breast cancer. Am J Obstet Gynecol. 2010; 203(6):595:e599-516.

12. Berno V, Amazit L, Hinojos C, Zhong J, Mancini MG, Sharp ZD and Mancini MA. Activation of estrogen receptor-alpha by E2 or EGF induces temporally distinct patterns of large-scale chromatin modification and mRNA transcription. PLoS One. 2008; 3(5):e2286.

13. Richardson AE, Hamilton N, Davis W, Brito C and De Leon D. Insulin-like growth factor-2 (IGF-2) activates estrogen receptor-alpha and -beta via the IGF-1 and the insulin receptors in breast cancer cells. Growth Factors. 2011; 29(2-3):82-93.

14. Miyamoto H, Yao JL, Chaux A, Zheng Y, Hsu I, Izumi K, Chang C, Messing EM, Netto GJ and Yeh S. Expression of androgen and oestrogen receptors and its prognostic significance in urothelial neoplasm of the urinary bladder. BJU Int. 2012; 109(11):1716-1726.

15. Basakci A, Kirkali Z, Tuzel E, Yorukoglu K, Mungan MU and Sade M. Prognostic significance of estrogen receptor expression in superficial transitional cell carcinoma of the urinary bladder. Eur Urol. 2002; 41(3):342-345.

16. Teng J, Wang ZY, Jarrard DF and Bjorling DE. Roles of estrogen receptor alpha and beta in modulating urothelial cell proliferation. Endocr Relat Cancer. 2008; 15(1): 351-364.

17. Goldstein NS, Ferkowicz M, Odish E, Mani A and Hastah F. Minimum formalin fixation time for consistent estrogen receptor immunohistochemical staining of invasive breast carcinoma. Am J Clin Pathol. 2003; 120(1):86-92.

18. Skliris GP, Parkes AT, Limer JL, Burdall SE, Carder PJ and Speirs V. Evaluation of seven oestrogen receptor beta antibodies for immunohistochemistry, western blotting, and flow cytometry in human breast tissue. J Pathol. 2002; 197(2):155-162.

19. Zhang ZT, Pak J, Huang HY, Shapiro E, Sun TT, Pellicer A and $\mathrm{Wu} \mathrm{XR}$. Role of Ha-ras activation in superficial papillary pathway of urothelial tumor formation. Oncogene. 2001; 20(16):1973-1980.

20. Zhang ZT, Pak J, Shapiro E, Sun TT and Wu XR. Urothelium-specific expression of an oncogene in 
transgenic mice induced the formation of carcinoma in situ and invasive transitional cell carcinoma. Cancer Res. 1999; 59(14):3512-3517.

21. Morimura K, Yamamoto S, Murai T, Mori S, Chen TX, Wanibuchi $\mathrm{H}$ and Fukushima S. LOH and mutational analysis of p53 alleles in mouse urinary bladder carcinomas induced by N-butyl-N-(4-hydroxybutyl) nitrosamine. Carcinogenesis. 1999; 20(4):715-718.

22. Yamamoto S, Masui T, Murai T, Mori S, Oohara T, Makino S, Fukushima $\mathrm{S}$ and Tatematsu M. Frequent mutations of the p53 gene and infrequent $\mathrm{H}$ - and $\mathrm{K}$-ras mutations in urinary bladder carcinomas of NON/Shi mice treated with N-butyl-N-(4-hydroxybutyl)nitrosamine. Carcinogenesis. 1995; 16(10):2363-2368.

23. Fukushima S, Hirose M, Tsuda H, Shirai T and Hirao K. Histological classification of urinary bladder cancers in rats induced by N-butyl-n-(4-hydroxybutyl)nitrosamine. Gann. 1976; 67(1):81-90.

24. Williams PD, Lee JK and Theodorescu D. Molecular credentialing of rodent bladder carcinogenesis models. Neoplasia. 2008; 10(8):838-846.

25. Cheng HL, Trink B, Tzai TS, Liu HS, Chan SH, Ho CL, Sidransky D and Chow NH. Overexpression of c-met as a prognostic indicator for transitional cell carcinoma of the urinary bladder: a comparison with p53 nuclear accumulation. J Clin Oncol. 2002; 20(6):1544-1550.

26. Guo S, Mao X, Chen J, Huang B, Jin C, Xu Z and Qiu S. Overexpression of Pim-1 in bladder cancer. J Exp Clin Cancer Res. 2010; 29:161.

27. Hodgson MC, Shao LJ, Frolov A, Li R, Peterson LE, Ayala G, Ittmann MM, Weigel NL and Agoulnik IU. Decreased expression and androgen regulation of the tumor suppressor gene INPP4B in prostate cancer. Cancer Res. 2011; 71(2):572-582.

28. Fedele CG, Ooms LM, Ho M, Vieusseux J, O’Toole SA, Millar EK, Lopez-Knowles E, Sriratana A, Gurung R, Baglietto L, Giles GG, Bailey CG, Rasko JE, Shields BJ, Price JT and Majerus PW. Inositol polyphosphate 4-phosphatase II regulates PI3K/Akt signaling and is lost in human basal-like breast cancers. Proc Natl Acad Sci U S A. 2010; 107(51):22231-22236.

29. Gewinner C, Wang ZC, Richardson A, Teruya-Feldstein J, Etemadmoghadam D, Bowtell D, Barretina J, Lin WM, Rameh L, Salmena L, Pandolfi PP and Cantley LC. Evidence that inositol polyphosphate 4-phosphatase type II is a tumor suppressor that inhibits PI3K signaling. Cancer Cell. 2009; 16(2):115-125.

30. Agoulnik IU, Hodgson MC, Bowden WA and Ittmann MM. INPP4B: the new kid on the PI3K block. Oncotarget. 2011; 2(4):321-328.

31. Dyrskjot L, Kruhoffer M, Thykjaer T, Marcussen N, Jensen JL, Moller K and Orntoft TF. Gene expression in the urinary bladder: a common carcinoma in situ gene expression signature exists disregarding histopathological classification. Cancer Res. 2004; 64(11):4040-4048.

32. Lee JS, Leem SH, Lee SY, Kim SC, Park ES, Kim SB, Kim SK, Kim YJ, Kim WJ and Chu IS. Expression signature of E2F1 and its associated genes predict superficial to invasive progression of bladder tumors. J Clin Oncol. 2010; 28(16):2660-2667.

33. Sanchez-Carbayo M, Socci ND, Lozano J, Saint F and Cordon-Cardo C. Defining molecular profiles of poor outcome in patients with invasive bladder cancer using oligonucleotide microarrays. J Clin Oncol. 2006; 24(5):778-789.

34. Vitkus S, Yeh CR, Lin HH, Hsu I, Yu J, Chen M and Yeh S. Distinct function of estrogen receptor alpha in smooth muscle and fibroblast cells in prostate development. Mol Endocrinol. 2013; 27(1):38-49.

35. Chen M, Yeh CR, Chang HC, Vitkus S, Wen XQ, Bhowmick NA, Wolfe A and Yeh S. Loss of epithelial oestrogen receptor alpha inhibits oestrogen-stimulated prostate proliferation and squamous metaplasia via in vivo tissue selective knockout models. J Pathol. 2012; 226(1):17-27.

36. Chen M, Hsu I, Wolfe A, Radovick S, Huang K, Yu S, Chang C, Messing EM and Yeh S. Defects of prostate development and reproductive system in the estrogen receptor-alpha null male mice. Endocrinology. 2009; 150(1):251-259.

37. Choudhary S, Hegde P, Pruitt JR, Sielecki TM, Choudhary D, Scarpato K, Degraff DJ, Pilbeam CC and Taylor JA 3rd. Macrophage migratory inhibitory factor promotes bladder cancer progression via increasing proliferation and angiogenesis. Carcinogenesis. 2013.

38. Hsu JW, Hsu I, Xu D, Miyamoto H, Liang L, Wu XR, Shyr CR and Chang C. Decreased tumorigenesis and mortality from bladder cancer in mice lacking urothelial androgen receptor. Am J Pathol. 2013; 182(5):1811-1820.

39. Mo L, Cheng J, Lee EY, Sun TT and Wu XR. Gene deletion in urothelium by specific expression of Cre recombinase. Am J Physiol Renal Physiol. 2005; 289(3):F562-568.

40. Reznikoff CA, Loretz LJ, Christian BJ, Wu SQ and Meisner LF. Neoplastic transformation of SV40immortalized human urinary tract epithelial cells by in vitro exposure to 3-methylcholanthrene. Carcinogenesis. 1988; 9(8):1427-1436.

41. Green KA and Carroll JS. Oestrogen-receptor-mediated transcription and the influence of co-factors and chromatin state. Nat Rev Cancer. 2007; 7(9):713-722.

42. Carroll JS, Meyer CA, Song J, Li W, Geistlinger TR, Eeckhoute J, Brodsky AS, Keeton EK, Fertuck KC, Hall GF, Wang Q, Bekiranov S, Sementchenko V, Fox EA, Silver PA and Gingeras TR. Genome-wide analysis of estrogen receptor binding sites. Nat Genet. 2006; 38(11):1289-1297. 
43. Gross JM and Yee D. How does the estrogen receptor work? Breast Cancer Res. 2002; 4(2):62-64.

44. Brasseur K, Leblanc V, Fabi F, Parent S, Descoteaux C, Berube $\mathrm{G}$ and Asselin E. ERalpha-targeted therapy in ovarian cancer cells by a novel estradiol-platinum(II) hybrid. Endocrinology. 2013; 154(7):2281-2295.

45. Yue W, Yager JD, Wang JP, Jupe ER and Santen RJ. Estrogen receptor-dependent and independent mechanisms of breast cancer carcinogenesis. Steroids. 2013; 78(2): 161-170.

46. Abot A, Fontaine C, Raymond-Letron I, Flouriot G, Adlanmerini M, Buscato M, Otto C, Berges H, Laurell H, Gourdy P, Lenfant F and Arnal JF. The AF-1 activation function of estrogen receptor alpha is necessary and sufficient for uterine epithelial cell proliferation in vivo. Endocrinology. 2013; 154(6):2222-2233.

47. Naugler WE, Sakurai T, Kim S, Maeda S, Kim K, Elsharkawy AM and Karin M. Gender disparity in liver cancer due to sex differences in MyD88-dependent IL-6 production. Science. 2007; 317(5834):121-124.

48. McCashland TM, Brand R, Lyden E and de Garmo P. Gender differences in colorectal polyps and tumors. Am J Gastroenterol. 2001; 96(3):882-886.

49. Liu WH, Yeh SH, Lu CC, Yu SL, Chen HY, Lin CY, Chen DS and Chen PJ. MicroRNA-18a prevents estrogen receptor-alpha expression, promoting proliferation of hepatocellular carcinoma cells. Gastroenterology. 2009; 136(2):683-693.

50. Okajima E, Hiramatsu $T$, Iriya $K$, Ijuin $M$ and Matsushima S. Effects of sex hormones on development of urinary bladder tumours in rats induced by N-butylN-(4-hydroxybutyl) nitrosamine. Urol Res. 1975; 3(2): 73-79.

51. Shen SS, Smith CL, Hsieh JT, Yu J, Kim IY, Jian W, Sonpavde G, Ayala GE, Younes M and Lerner SP. Expression of estrogen receptors-alpha and -beta in bladder cancer cell lines and human bladder tumor tissue. Cancer. 2006; 106(12):2610-2616.

52. Botelho MC, Ribeiro R, Vale N, Oliveira P, Medeiros R, Lopes $\mathrm{C}$, Machado JC and Correia da Costa JM. Inactivation of estrogen receptor by Schistosoma haematobium total antigen in bladder urothelial cells. Oncol Rep. 2011; 27(2):356-362.

53. Davey JC, Bodwell JE, Gosse JA and Hamilton JW. Arsenic as an endocrine disruptor: effects of arsenic on estrogen receptor-mediated gene expression in vivo and in cell culture. Toxicol Sci. 2007; 98(1):75-86.

54. Anghel A, Narita D, Seclaman E, Popovici E, Anghel M and Tamas L. Estrogen receptor alpha polymorphisms and the risk of malignancies. Pathol Oncol Res. 2010; 16(4):485-496.

55. Sonpavde G, Okuno N, Weiss H, Yu J, Shen SS, Younes M, Jian W, Lerner SP and Smith CL. Efficacy of selective estrogen receptor modulators in nude mice bearing human transitional cell carcinoma. Urology. 2007; 69(6): 1221-1226.

56. Hsu I, Chuang KL, Slavin S, Da J, Lim WX, Pang ST, O'Brien JH and Yeh S. Suppression of ERbeta signaling via ERbeta knockout or antagonist protects against bladder cancer development. Carcinogenesis. 2013.

57. Hsu I, Vitkus S, Da J and Yeh S. Role of oestrogen receptors in bladder cancer development. Nat Rev Urol. 2013; 10(6):317-326.

58. Goldberg SI, Niemierko A and Turchin A. Analysis of data errors in clinical research databases. AMIA Annual Symposium proceedings/AMIA Symposium AMIA Symposium. 2008; :242-246.

59. Balakrishnan A and Chaillet JR. Role of the inositol polyphosphate-4-phosphatase type II Inpp4b in the generation of ovarian teratomas. Dev Biol. 2013; 373(1):118-129.

60. McGrath M, Michaud DS and De Vivo I. Hormonal and reproductive factors and the risk of bladder cancer in women. Am J Epidemiol. 2006; 163(3):236-244.

61. Dietrich K, Demidenko E, Schned A, Zens MS, Heaney J and Karagas MR. Parity, early menopause and the incidence of bladder cancer in women: a case-control study and metaanalysis. Eur J Cancer. 2010; 47(4):592-599.

62. Cantor KP, Lynch CF and Johnson D. Bladder cancer, parity, and age at first birth. Cancer Causes Control. 1992; 3(1):57-62.

63. Wolpert BJ, Amr S, Ezzat S, Saleh D, Gouda I, Loay I, Hifnawy T, Mikhail NN, Abdel-Hamid M, Zhan M, Zheng YL, Squibb K, Abdel-Aziz MA, Zaghloul M, Khaled $\mathrm{H}$ and Loffredo CA. Estrogen exposure and bladder cancer risk in Egyptian women. Maturitas. 2010; 67(4):353-357.

64. Davis-Dao CA, Henderson KD, Sullivan-Halley J, Ma H, West D, Xiang YB, Gago-Dominguez M, Stern MC, Castelao JE, Conti DV, Pike MC, Bernstein L and Cortessis VK. Lower risk in parous women suggests that hormonal factors are important in bladder cancer etiology. Cancer Epidemiol Biomarkers Prev. 2011; 20(6):1156-1170.

65. Huang AT, Kogevinas M, Silverman DT, Malats N, Rothman N, Tardon A, Serra C, Garcia-Closas R, Carrato A and Cantor KP. Bladder cancer and reproductive factors among women in Spain. Cancer Causes Control. 2009; 20(10):1907-1913.

66. Weis KE, Ekena K, Thomas JA, Lazennec G and Katzenellenbogen BS. Constitutively active human estrogen receptors containing amino acid substitutions for tyrosine 537 in the receptor protein. Mol Endocrinol. 1996; 10(11):1388-1398.

67. Merenbakh-Lamin K, Ben-Baruch N, Yeheskel A, Dvir A, Soussan-Gutman L, Jeselsohn R, Yelensky R, Brown M, Miller VA, Sarid D, Rizel S, Klein B, Rubinek T and 
Wolf I. D538G mutation in estrogen receptor-alpha: A novel mechanism for acquired endocrine resistance in breast cancer. Cancer Res. 2013; 73(23):6856-6864.

68. Sun $\mathrm{CH}$, Chang YH and Pan CC. Activation of the PI3K/ Akt/mTOR pathway correlates with tumour progression and reduced survival in patients with urothelial carcinoma of the urinary bladder. Histopathology. 2011; 58(7):1054-1063.

69. Davies BR, Greenwood H, Dudley P, Crafter C, Yu DH, Zhang J, Li J, Gao B, Ji Q, Maynard J, Ricketts SA, Cross D, Cosulich S, Chresta CC, Page K and Yates J. Preclinical Pharmacology of AZD5363, an Inhibitor of AKT: Pharmacodynamics, Antitumor Activity, and Correlation of Monotherapy Activity with Genetic Background. Mol Cancer Ther. 2012; 11(4):873-887.

70. Sangai T, Akcakanat A, Chen H, Tarco E, Wu Y, Do KA, Miller TW, Arteaga CL, Mills GB, Gonzalez-Angulo AM and Meric-Bernstam F. Biomarkers of response to Akt inhibitor MK-2206 in breast cancer. Clin Cancer Res. 2012; 18(20):5816-5828.

71. Mandal M, Kim S, Younes MN, Jasser SA, El-Naggar AK, Mills GB and Myers JN. The Akt inhibitor KP372-1 suppresses Akt activity and cell proliferation and induces apoptosis in thyroid cancer cells. Br J Cancer. 2005; 92(10):1899-1905.

72. Chen M, Wolfe A, Wang X, Chang C, Yeh S and Radovick S. Generation and characterization of a complete null estrogen receptor alpha mouse using Cre/ LoxP technology. Mol Cell Biochem. 2009; 321(1-2): 145-153.

73. Chen M, Yeh CR, Chang HC, Vitkus S, Wen XQ, Bhowmick NA, Wolfe A and Yeh S. Loss of epithelial oestrogen receptor alpha inhibits oestrogen-stimulated prostate proliferation and squamous metaplasia via in vivo tissue selective knockout models. J Pathol. 2011; 226(1):17-27.

74. Flicek P, Amode MR, Barrell D, Beal K, Billis K, Brent S, Carvalho-Silva D, Clapham P, Coates G, Fitzgerald S, Gil L, Giron CG, Gordon L, Hourlier T, Hunt S and Johnson N. Ensembl 2014. Nucleic Acids Res. 2014; 42(Database issue):D749-755.

75. Miyamoto H, Miller JS, Fajardo DA, Lee TK, Netto GJ and Epstein JI. Non-invasive papillary urothelial neoplasms: the $2004 \mathrm{WHO} / \mathrm{ISUP}$ classification system. Pathology international. 2010; 60(1):1-8. 